\title{
Molybdenum(VI) Oxosulfato Complexes in MoO3-K2S2O7-K2SO4 Molten Mixtures: Stoichiometry, Vibrational Properties, and Molecular Structures
}

\author{
Kalampounias, Angelos G.; Tsilomelekis, George; Berg, Rolf W.; Boghosian, Soghomon
}

Published in:

Journal of Physical Chemistry Part A: Molecules, Spectroscopy, Kinetics, Environment and General Theory

Link to article, DOI:

10.1021/jp306701k

Publication date:

2012

Document Version

Publisher's PDF, also known as Version of record

Link back to DTU Orbit

Citation (APA):

Kalampounias, A. G., Tsilomelekis, G., Berg, R. W., \& Boghosian, S. (2012). Molybdenum(VI) Oxosulfato Complexes in $\mathrm{MoO}_{3}-\mathrm{K}_{2} \mathrm{~S}_{2} \mathrm{O}_{7}-\mathrm{K}_{2} \mathrm{SO}_{4}$ Molten Mixtures: Stoichiometry, Vibrational Properties, and Molecular Structures. Journalof Physical Chemistry Part A: Molecules, Spectroscopy, Kinetics, Environment and General Theory, 116(35), 8861-8872. https://doi.org/10.1021/jp306701k

\section{General rights}

Copyright and moral rights for the publications made accessible in the public portal are retained by the authors and/or other copyright owners and it is a condition of accessing publications that users recognise and abide by the legal requirements associated with these rights.

- Users may download and print one copy of any publication from the public portal for the purpose of private study or research.

- You may not further distribute the material or use it for any profit-making activity or commercial gain

- You may freely distribute the URL identifying the publication in the public portal 


\title{
Molybdenum(VI) Oxosulfato Complexes in $\mathrm{MoO}_{3}-\mathrm{K}_{2} \mathrm{~S}_{2} \mathrm{O}_{7}-\mathrm{K}_{2} \mathrm{SO}_{4}$ Molten Mixtures: Stoichiometry, Vibrational Properties, and Molecular Structures
}

\author{
Angelos G. Kalampounias, ${ }^{\dagger}$ George Tsilomelekis, ${ }^{\dagger}$ Rolf W. Berg, ${ }^{\ddagger}$ and Soghomon Boghosian* ${ }^{\dagger}$
}

${ }^{\dagger}$ Department of Chemical Engineering, University of Patras and Institute of Chemical Engineering and High Temperature Chemical Processes (FORTH/ICE-HT), GR-26500 Patras, Greece

${ }^{\ddagger}$ Chemistry Department, The Technical University of Denmark, DK-2800 Kongens Lyngby, Denmark

Supporting Information

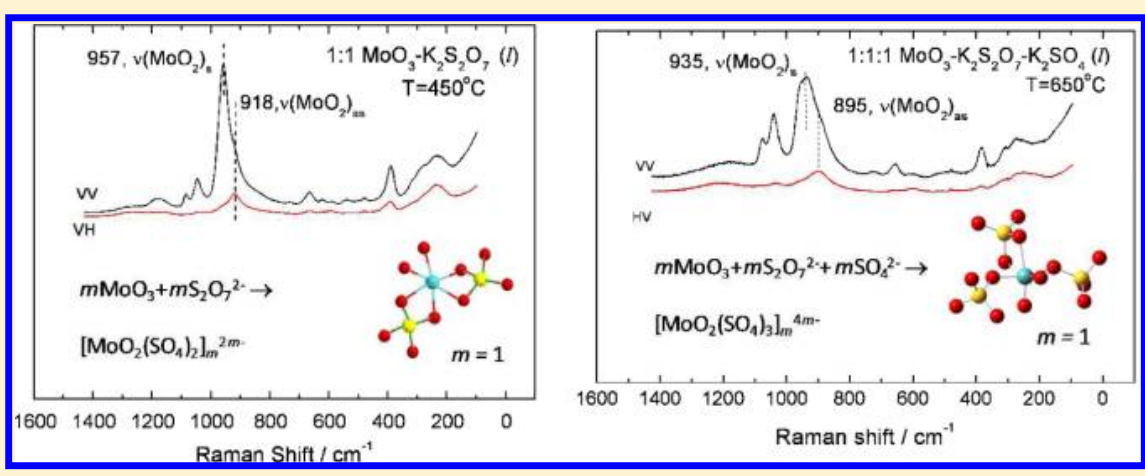

ABSTRACT: The structural and vibrational properties of molybdenum(VI) oxosulfato complexes formed in $\mathrm{MoO}_{3}-\mathrm{K}_{2} \mathrm{~S}_{2} \mathrm{O}_{7}$ and $\mathrm{MoO}_{3}-\mathrm{K}_{2} \mathrm{~S}_{2} \mathrm{O}_{7}-\mathrm{K}_{2} \mathrm{SO}_{4}$ molten mixtures under an $\mathrm{O}_{2}$ atmosphere and static equilibrium conditions were studied by Raman spectroscopy at temperatures of $400-640{ }^{\circ} \mathrm{C}$. The corresponding composition effects were explored in the $X_{\mathrm{MoO}_{3}}^{0}=0-0.5$ range. $\mathrm{MoO}_{3}$ undergoes a dissolution reaction in molten $\mathrm{K}_{2} \mathrm{~S}_{2} \mathrm{O}_{7}$, and the Raman spectra point to the formation of molybdenum(VI) oxosulfato complexes. The $\mathrm{Mo}=\mathrm{O}$ stretching region of the Raman spectrum provides sound evidence for the occurrence of a dioxo $\mathrm{Mo}(=\mathrm{O})_{2}$ configuration as a core. The stoichiometry of the dissolution reaction $\mathrm{MoO}_{3}+n \mathrm{~S}_{2} \mathrm{O}_{7}{ }^{2-} \rightarrow \mathrm{C}^{2 n-}$ was inferred by exploiting the Raman band intensities, and it was found that $n=1$. Therefore, depending on the $\mathrm{MoO}_{3}$ content, monomeric $\mathrm{MoO}_{2}\left(\mathrm{SO}_{4}\right)_{2}{ }^{2-}$ and/or associated $\left[\mathrm{MoO}_{2}\left(\mathrm{SO}_{4}\right)_{2}\right]_{m}{ }^{2 m-}$ complexes are formed in the binary $\mathrm{MoO}_{3}-\mathrm{K}_{2} \mathrm{~S}_{2} \mathrm{O}_{7}$ molten system, and pertinent structural models are proposed in full consistency with the Raman data. A 6-fold coordination around Mo is inferred. Adjacent $\mathrm{MoO}_{2}{ }^{2+}$ cores are linked by bidentate bridging sulfates. With increasing temperature at concentrated melts (i.e., high $\left.\mathrm{X}_{\mathrm{MoO}_{3}}^{0}\right)$, the observed spectral changes can be explained by partial dissociation of $\left[\mathrm{MoO}_{2}\left(\mathrm{SO}_{4}\right)_{2}\right]_{m}{ }^{2 m-}$ by detachment of $\mathrm{S}_{2} \mathrm{O}_{7}{ }^{2-}$ and formation of a Mo-O-Mo bridge. Addition of $\mathrm{K}_{2} \mathrm{SO}_{4}$ in $\mathrm{MoO}_{3}-\mathrm{K}_{2} \mathrm{~S}_{2} \mathrm{O}_{7}$ results in a "follow-up" reaction and formation of $\mathrm{MoO}_{2}\left(\mathrm{SO}_{4}\right)_{3}{ }^{4-}$ and/or associated $\left[\mathrm{MoO}_{2}\left(\mathrm{SO}_{4}\right)_{3}\right]_{m}{ }^{4 m-}$ complexes in the ternary $\mathrm{MoO}_{3}-\mathrm{K}_{2} \mathrm{~S}_{2} \mathrm{O}_{7}-\mathrm{K}_{2} \mathrm{SO}_{4}$ molten system. The 6fold Mo coordination comprises two oxide ligands and four $\mathrm{O}$ atoms linking to coordinated sulfate groups in various environments of reduced symmetry. The most characteristic Raman bands for the molybdenum(VI) oxosulfato complexes pertain to the $\mathrm{Mo}(=\mathrm{O})_{2}$ stretching modes: (1) at 957 (polarized) and 918 (depolarized) $\mathrm{cm}^{-1}$ for the $\nu_{\mathrm{s}}$ and $\nu_{\text {as }} \mathrm{Mo}(=\mathrm{O})_{2}$ modes of $\mathrm{MoO}_{2}\left(\mathrm{SO}_{4}\right)_{2}{ }^{2-}$ and $\left[\mathrm{MoO}_{2}\left(\mathrm{SO}_{4}\right)_{2}\right]_{m}{ }^{2 m-}$ and (2) at 935 (polarized) and 895 (depolarized) $\mathrm{cm}^{-1}$ for the respective modes of $\mathrm{MoO}_{2}\left(\mathrm{SO}_{4}\right)_{3}{ }^{4-}$ and $\left[\mathrm{MoO}_{2}\left(\mathrm{SO}_{4}\right)_{3}\right]_{m}{ }^{4 m-}$. The results were tested and found to be in accordance with ab initio quantum chemical calculations carried out on $\left[\mathrm{MoO}_{2}\left(\mathrm{SO}_{4}\right)_{3}\right]^{4-}$ and $\left[\left\{\mathrm{MoO}_{2}\right\}_{2}\left(\mathrm{SO}_{4}\right)_{4}\left(\mu-\mathrm{SO}_{4}\right)_{2}\right]^{8-}$ ions, in assumed isolated gaseous free states, at the DFT/B3LYP (HF) level and with the 3-21G basis set. The calculations included determination of vibrational infrared and Raman spectra, by use of force constants in the Gaussian 03W program.

\section{INTRODUCTION}

The structure of the vanadium $(\mathrm{V})$ oxosulfato complexes formed following the dissolution of $\mathrm{V}_{2} \mathrm{O}_{5}$ in molten alkali pyrosulfates, alkali sulfates, and mixtures thereof has been studied extensively ${ }^{1-3}$ because of the importance of the pertinent molten salts as constituents of the supported liquid catalytic phase of the sulfuric acid catalyst. ${ }^{4}$ Interestingly, a number of other transition-metal oxides have also been found to exhibit solubility in molten alkali pyrosulfate and alkali pyrosulfate/alkali sulfate mixtures, forming metal oxosulfato complexes. A procedure for inferring the stoichiometry of such solutes in molten salt solvents has been derived, based on

Received: July 6, 2012

Revised: August 14, 2012

Published: August 14, 2012 
Raman band intensity correlations. ${ }^{5}$ The dissolution of metal oxides at moderate or elevated temperatures (such as in molten pyrosulfate) has drawn interest from the point of view of metal ore extraction and recovery of metal oxides (e.g., catalyst active phases consisting of $\mathrm{V}_{2} \mathrm{O}_{5}, \mathrm{WO}_{3}, \mathrm{Nb}_{2} \mathrm{O}_{5}, \mathrm{MoO}_{3}, \mathrm{ZnO}$; catalyst carriers such as $\mathrm{TiO}_{2}, \mathrm{ZrO}_{2}$ ). Thus, high-temperature Raman spectroscopy has been used for establishing the stoichiometry as well as the structural and vibrational properties of the metal oxosulfato complexes formed by dissolution of $\mathrm{ZnO}$ in molten $\mathrm{K}_{2} \mathrm{~S}_{2} \mathrm{O}_{7}$ and $\mathrm{Na}_{2} \mathrm{~S}_{2} \mathrm{O}_{7}{ }^{6}$ and of $\mathrm{Nb}_{2} \mathrm{O}_{5}$ and $\mathrm{WO}_{3}$ in molten $\mathrm{K}_{2} \mathrm{~S}_{2} \mathrm{O}_{7}$ and $\mathrm{K}_{2} \mathrm{~S}_{2} \mathrm{O}_{7}-\mathrm{K}_{2} \mathrm{SO}_{4}{ }^{7,8}$ In addition, by cooling the respective precursor melts under appropriate gas atmospheres, a large family of crystalline compounds has been synthesized and subjected to single-crystal $\mathrm{X}$-ray analysis, thereby enabling the structural characterization of $\mathrm{V}^{\mathrm{III}},{ }^{9-11} \mathrm{~V}^{\mathrm{IV}}, \mathrm{1}^{12-15} \mathrm{~V}^{\mathrm{V}},{ }^{16,17}$ $\mathrm{Nb}^{\mathrm{V}, 18} \mathrm{Ta}^{\mathrm{V}}, \mathrm{W}^{\mathrm{VI}},{ }^{19-21}$ and $\mathrm{Mo}^{\mathrm{VI}} 22,23$ crystalline sulfato or oxosulfato complexes. Notably, the precipitation of $\mathrm{V}^{\mathrm{III}}, \mathrm{V}^{\mathrm{IV}}$, and $\mathrm{V}^{\mathrm{V}}$ crystalline salts has been shown to be responsible for the deactivation of the sulfuric acid catalyst, causing depletion of the active phase from its $\mathrm{V}$ content. ${ }^{4,24-26}$

Although the type of complexes formed during the dissolution of molybdenum(VI) oxide in pure molten alkali pyrosulfate is not known, it is expected that $\mathrm{Mo}^{\mathrm{VI}}$ forms anionic sulfato and/or oxosulfato complexes in molten pyrosulfates in analogy to $\mathrm{V}^{\mathrm{V}}, \mathrm{Nb}^{\mathrm{V}}, 7$ and $\mathrm{W}^{\mathrm{VI}}$. concerned with the structural and vibrational properties of the complexes formed in the molten binary $\mathrm{MoO}_{3}-\mathrm{K}_{2} \mathrm{~S}_{2} \mathrm{O}_{7}$ and ternary $\mathrm{MoO}_{3}-\mathrm{K}_{2} \mathrm{~S}_{2} \mathrm{O}_{7}-\mathrm{K}_{2} \mathrm{SO}_{4}$ systems. Raman spectroscopy was used at temperatures of $400-650{ }^{\circ} \mathrm{C}$ under static equilibrium conditions for studying the molten mixtures with $X_{\mathrm{MoO}_{3}}^{0}=0-0.5\left(X_{\mathrm{MoO}_{3}}^{0}\right.$ denotes the initial $\mathrm{MoO}_{3}$ mole fraction in the $\mathrm{MoO}_{3}-\mathrm{K}_{2} \mathrm{~S}_{2} \mathrm{O}_{7}$ binary mixture). Incremental amounts of $\mathrm{K}_{2} \mathrm{SO}_{4}$ were added to each binary mixture with $n\left(\mathrm{SO}_{4}{ }^{2-}\right)$ / $n(\mathrm{Mo})=0-2$, where $n\left(\mathrm{SO}_{4}{ }^{2-}\right) / n(\mathrm{Mo})$ (hereafter denoted $Y$ ) is the number of moles of $\mathrm{K}_{2} \mathrm{SO}_{4}$ added per Mo atom in each mixture. The use of the Raman data obtained for the molten mixtures is shown to be adequate for inferring the stoichiometry of the $\mathrm{MoO}_{3}$ dissolution reaction

$$
\mathrm{MoO}_{3}+n \mathrm{~S}_{2} \mathrm{O}_{7}^{2-} \rightarrow \mathrm{C}^{2 n-}
$$

The effects of temperature and composition on the Raman spectra of the $\mathrm{MoO}_{3}-\mathrm{K}_{2} \mathrm{~S}_{2} \mathrm{O}_{7}$ and $\mathrm{MoO}_{3}-\mathrm{K}_{2} \mathrm{~S}_{2} \mathrm{O}_{7}-\mathrm{K}_{2} \mathrm{SO}_{4}$ systems were investigated to establish the existence of the structural units present in conjunction with consistent experimental band assignments also based on comparison to theoretical spectra predicted by ab initio DFT/B3LYP calculations with Gaussian 3-21G basis sets. These results add detailed confidence to our present understanding of the chemistry of the systems. Moreover, from the point of view of more topical interest, the Raman band characteristics (i.e., band wavenumber, intensity and polarization properties) of $\mathrm{Mo}=\mathrm{O}$ stretching modes in oxomolybdenum cores of molybdenum(VI) oxosulfato complexes are expected to shed additional light in the debate concerning the configuration of $\left(\mathrm{MoO}_{x}\right)_{n}$ sites in supported $\mathrm{MoO}_{3}$ catalysts. ${ }^{27-30}$

\section{EXPERIMENTAL SECTION}

Materials and Sample Preparation. The samples were prepared by mixing $\mathrm{MoO}_{3}$ (Alfa Aesar, dried in vacuo for $1 \mathrm{~h}$ at $140{ }^{\circ} \mathrm{C}$ before use) with $\mathrm{K}_{2} \mathrm{SO}_{4}$ (Fluka) and $\mathrm{K}_{2} \mathrm{~S}_{2} \mathrm{O}_{7}$ made by thermal decomposition of $\mathrm{K}_{2} \mathrm{~S}_{2} \mathrm{O}_{8}$ (Fluka), as described previously. ${ }^{31}$ All handling of chemicals and filling of the
Raman optical cells [made of cylindrical fused silica tubing $(6 \pm$ $0.1 \mathrm{~mm}$ o.d., $4 \pm 0.1 \mathrm{~mm}$ i.d., and $\sim 3 \mathrm{~cm}$ length for the part containing the molten salts)] took place in a dry nitrogen-filled glovebox. The total amount of salt mixture added into each cell was $400 \mathrm{mg}$. Proper mixing of the components was necessary, as the melting point of $\mathrm{MoO}_{3}\left(795{ }^{\circ} \mathrm{C}\right)$ is very high compared to the fusion temperatures of the $\mathrm{MoO}_{3}-\mathrm{K}_{2} \mathrm{~S}_{2} \mathrm{O}_{7}$ and $\mathrm{MoO}_{3}-$ $\mathrm{K}_{2} \mathrm{~S}_{2} \mathrm{O}_{7}-\mathrm{K}_{2} \mathrm{SO}_{4}$ mixtures. Thus, the optical cells were filled either by transferring $\mathrm{MoO}_{3}$ and $\mathrm{K}_{2} \mathrm{SO}_{4}$ with approximately one-half of the $\mathrm{K}_{2} \mathrm{~S}_{2} \mathrm{O}_{7}$ into the cell and then adding the remaining $\mathrm{K}_{2} \mathrm{~S}_{2} \mathrm{O}_{7}$ on top or by grinding all components intimately in an agate mortar before transferring the mixture into the optical cell. The samples were sealed under a low pressure (ca. 0.2 bar) of $\mathrm{O}_{2}$ (L'Air Liquide, 99.99\%) to prevent self-reduction of $\mathrm{Mo}^{\mathrm{VI}}$. Afterward, they were equilibrated at 500-550 ${ }^{\circ} \mathrm{C}$ for a few days (up to 1 week) before Raman spectra were recorded. The dissolution of $\mathrm{MoO}_{3}$ in molten $\mathrm{K}_{2} \mathrm{~S}_{2} \mathrm{O}_{7}$, although slow, was extensive; it was possible to dissolve up to $50 \mathrm{~mol} \% \mathrm{MoO}_{3}$. Upon dissolution of white molybdenum oxide in colorless molten potassium pyrosulfate, the resulting melts became transparent yellow (pale to dark depending on the $\mathrm{MoO}_{3}$ content) and viscous. Intermittently, it was necessary to remove bubbles and/or accelerate the dissolution of solids by torching the samples. Lowering the sample temperature could cause the appearance of white needles in the bulk melt, presumably due to the precipitation of crystalline complexes. Fast cooling of samples with high $\mathrm{MoO}_{3}$ contents by immersion in water or liquid nitrogen led to the formation of glasses.

The symbol $X_{i}^{0}$ is used to denote the mole fraction of unreacted component $i$ in the $\mathrm{MoO}_{3}-\mathrm{K}_{2} \mathrm{~S}_{2} \mathrm{O}_{7}$ binary mixture (weighed amount) before any reaction had started. The composition of the ternary mixture is defined by combining $X_{\mathrm{MoO}_{3}}^{0}$ (neglecting $\mathrm{K}_{2} \mathrm{SO}_{4}$ ) with the ratio $Y\left[Y=n\left(\mathrm{SO}_{4}{ }^{2-}\right) /\right.$ $n(\mathrm{Mo})]$ of the number of sulfate groups added per Mo atom, which was varied between 0 and 2 . After adequate equilibration at $550{ }^{\circ} \mathrm{C}$, all binary $\mathrm{MoO}_{3}-\mathrm{K}_{2} \mathrm{~S}_{2} \mathrm{O}_{7}$ mixtures with $X_{\mathrm{MoO}_{3}}^{0}=0-$ 0.5 were in the liquid (molten) state at $400{ }^{\circ} \mathrm{C}$. The dissolution of $\mathrm{MoO}_{3}$ was further facilitated in ternary mixtures where sulfate was also present. Table 1 and Figure 1 summarize the compositions of the samples made during the course of the present work.

Raman Spectroscopy. The Raman furnace for the optical cells and the systematics for obtaining Raman spectra from molten salts and vapors at high temperatures have been described in detail elsewhere.,3,5,32,33 Raman spectra were excited by the linearly polarized 532-nm line of an air-cooled diode-pumped continuous-wave laser (Excelsior series, SpectraPhysics). The laser power at the sample was set at $\sim 100 \mathrm{~mW}$. Raman spectra were recorded in a horizontal $90^{\circ}$ scattering geometry using a collecting lens system (90- and 150-mm focal lengths); the collected scattered light was passed through a notch filter to reject the Rayleigh scattering and analyzed with a Jobin-Yvon IHR-320 (ISA-Horiba group) monochromator equipped with a $-70{ }^{\circ} \mathrm{C}$ thermoelectrically cooled chargecoupled device detector. The notch was tilted such that bands could be detected quite close to the excitation line. The resolution of the instrument was set at $2 \mathrm{~cm}^{-1}$ for the whole set of measurements. Both polarized (VV, vertical polarization of the incident laser and vertical analysis of the scattered light) and depolarized ( $\mathrm{VH}$, vertical polarization of the incident laser and horizontal analysis of the scattered light) scattering 
Table 1. Relative Molar Compositions, $\mathrm{X}_{\mathrm{MoO}_{3}}^{0},{ }^{a}$ and Indicators of Incremental Sulfate Content, $n\left(\mathrm{SO}_{4}{ }^{2-}\right) / n(\mathrm{Mo})$, of $\mathrm{MoO}_{3}-\mathrm{K}_{2} \mathrm{~S}_{2} \mathrm{O}_{7}-\mathrm{K}_{2} \mathrm{SO}_{4}$ Samples, along with Ordinary Mole Fractions, ${ }^{b} \mathrm{X}_{\mathrm{MoO}_{3}}$ and $\mathrm{X}_{\mathrm{K}_{2} \mathrm{SO}_{4}}$

$\begin{array}{clcll}\text { cell no. } & X_{\mathrm{MoO}_{3}}^{0}{ }^{a} & Y=n\left(\mathrm{SO}_{4}{ }^{2-}\right) / n(\mathrm{Mo}) & X_{\mathrm{MoO}_{3}}{ }^{b} & X_{\mathrm{K}_{2} \mathrm{SO}_{4}}{ }^{b} \\ 1 & 0 & - & 0 & 0 \\ 2 & 0.102 & - & 0.102 & 0 \\ 3 & 0.200 & - & 0.200 & 0 \\ 4 & 0.249 & - & 0.249 & 0 \\ 5 & 0.330 & - & 0.330 & 0 \\ 6 & 0.402 & - & 0.402 & 0 \\ 7 & 0.500 & - & 0.500 & 0 \\ 8 & 0.201 & 0.51 & 0.182 & 0.093 \\ 9 & 0.203 & 0.99 & 0.169 & 0.167 \\ 10 & 0.203 & 1.98 & 0.145 & 0.286 \\ 11 & 0.249 & 0.51 & 0.221 & 0.112 \\ 12 & 0.250 & 1.01 & 0.199 & 0.202 \\ 13 & 0.249 & 2.01 & 0.166 & 0.333 \\ 14 & 0.329 & 0.50 & 0.283 & 0.142 \\ 15 & 0.329 & 1.01 & 0.247 & 0.249 \\ 16 & 0.330 & 2.00 & 0.199 & 0.397 \\ 17 & 0.500 & 0.51 & 0.398 & 0.202 \\ 18 & 0.499 & 1.01 & 0.332 & 0.335 \\ 19 & 0.497 & 2.01 & 0.249 & 0.500\end{array}$

${ }^{a} X_{\mathrm{MoO}_{3}}^{0}$ denotes the mol fractions of unreacted components of the $\mathrm{MoO}_{3}-\mathrm{K}_{2} \mathrm{~S}_{2} \mathrm{O}_{7}$ binary mixture (weighed amounts) before any reaction had started and any $\mathrm{K}_{2} \mathrm{SO}_{4}$ had been added. ${ }^{b} \mathrm{X}_{\mathrm{MoO}_{3}}, X_{\mathrm{K}_{2} \mathrm{SO}_{4}}$, and $\mathrm{X}_{\mathrm{K}_{2} \mathrm{SO}_{7}}$ denote the ordinary mole fractions, which sum to 1 in the homogeneous melt.

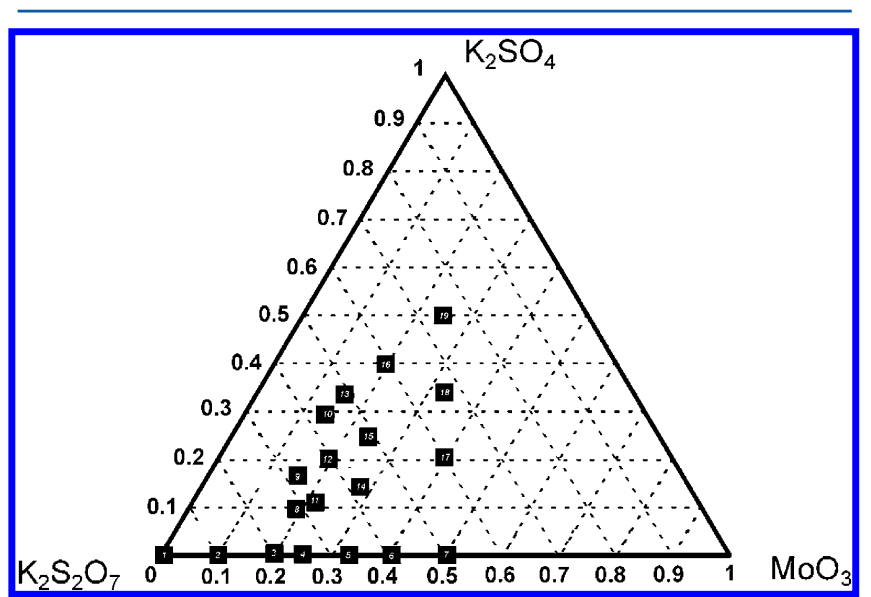

Figure 1. Ternary diagram of the mole fractions showing the compositions of the samples.

geometries were employed. This was achieved with the aid of a set of Glan and Glan-Thompson polarizers (Hale) with extinction coefficients better than $10^{-6}$ and $10^{-7}$, respectively. A calibration procedure using a $\mathrm{CCl}_{4}$ sample was regularly applied to check the polarization and possible monochromator drifts. Accumulation times were adjusted to provide a very high signalto-noise ratio.

Modeling Structure and Vibrational Spectroscopy. Ab initio quantum chemical molecular orbital calculations were performed using the Gaussian $03 \mathrm{~W}$ program package ${ }^{34}$ on a 3$\mathrm{GHz}$ personal computer as described previously. ${ }^{35}$ As input data, guessed geometries of monomeric $\mathrm{MoO}_{2}\left(\mathrm{SO}_{4}\right)_{3}{ }^{4-}$ and dimeric $\left[\left\{\mathrm{MoO}_{2}\right\}_{2}\left(\mathrm{SO}_{4}\right)_{4}\left(\mu-\mathrm{SO}_{4}\right)_{2}\right]^{8-}$ were used, constructed in analogy with the established structures of the $\mathrm{K}_{4}\left[\mathrm{MoO}_{2}\left(\mathrm{SO}_{4}\right)_{3}\right]^{22}$ and $\mathrm{K}_{8}\left[\left\{\mathrm{WO}_{2}\right\}_{2}\left(\mathrm{SO}_{4}\right)_{4}\left(\mu-\mathrm{SO}_{4}\right)_{2}\right]$ crystals. ${ }^{20}$ The geometries of ions in a hypothetical gaseous free state (without surrounding cations and without assuming any symmetry) were optimized, minimizing the electronic energy as a function of the geometry under tight optimization convergence criteria using the modified GDIIS algorithm. Hartree-Fock/Kohn-Sham density functional theory (DFT) procedures were used with the spin-restricted Becke's threeparameter approximation hybrid exchange functional (B3), the Lee-Yang-Parr correlation and exchange functions (LYP), and Pople's polarization split-valence Gaussian basis set functions without polarization functions or diffuse orbitals (B3LYP, 3-21G). The reason for this simple choice was the lack of a better set of functions for molybdenum. For $\left[\mathrm{MoO}_{2}\left(\mathrm{SO}_{4}\right)_{3}\right]^{4-}$, the DFT/B3LYP/3-21G procedure involved 408 basis functions, 756 primitive Gaussian functions, 408 Cartesian basis functions, and $206 \alpha$ and $206 \beta$ electrons. For the dimer, the calculation was about twice as complicated. The optimized results are given as sums of electronic and thermal free energies in atomic units (hartrees), not including the zeropoint energy correction. The vibrational frequencies and eigenvectors for each normal mode were calculated without adjusting force constants. The spectra were calculated with a factor of 1.22 scaling of the wavenumber values, and the high temperature was modeled by assuming Gaussian band shapes of $20 \mathrm{~cm}^{-1}$ half-widths at band half-heights.

\section{RESULTS AND DISCUSSION}

Raman Spectra of Binary $\mathrm{MoO}_{3}-\mathrm{K}_{2} \mathrm{~S}_{2} \mathrm{O}_{7}$ Molten Mixtures. Several cells were made, containing $\mathrm{MoO}_{3}-$ $\mathrm{K}_{2} \mathrm{~S}_{2} \mathrm{O}_{7}$ mixtures with initial $\mathrm{MoO}_{3}$ mole fractions in the range $X_{\mathrm{MoO}_{3}}^{0}=0-0.5$ (for sample compositions, see Table 1, cells $1-7)$; sealed under an oxygen atmosphere $\left(P_{\mathrm{O}_{2}}=0.2\right.$ atm); and heated until dissolution and equilibrium were attained. Raman spectra were recorded at four different temperatures in the range of $400-640{ }^{\circ} \mathrm{C}$. Figure 2 shows representative Raman spectra obtained for all molten $\mathrm{MoO}_{3}-$ $\mathrm{K}_{2} \mathrm{~S}_{2} \mathrm{O}_{7}$ samples at $450{ }^{\circ} \mathrm{C}$, together with the Raman spectra of pure molten $\mathrm{K}_{2} \mathrm{~S}_{2} \mathrm{O}_{7}$, which are well-known ${ }^{3,36}$ and are included in Figure 2 for comparison. The most characteristic bands due to the $\mathrm{S}_{2} \mathrm{O}_{7}{ }^{2-}$ ion in molten $\mathrm{K}_{2} \mathrm{~S}_{2} \mathrm{O}_{7}$ at $450{ }^{\circ} \mathrm{C}$ occur at 1085 $\mathrm{cm}^{-1}$ (terminal stretching), $730 \mathrm{~cm}^{-1}$ (bridging $\mathrm{S}-\mathrm{O}-\mathrm{S}$ stretching), and $318 \mathrm{~cm}^{-1}$ (S-O-S deformation). Upon dissolution of $\mathrm{MoO}_{3}$, several new bands emerge in the Raman spectra that can be attributed to $\mathrm{Mo}^{\mathrm{VI}}$ complex formation, and their wavenumbers and polarization characteristics are compiled in Table 2 . In total, 11 polarized and 5 depolarized bands are observed due to the $\mathrm{Mo}^{\mathrm{VI}}$ complex formed. Notably, with increasing formal content of $\mathrm{MoO}_{3}$, the intensities of all bands ascribed to the complex(es) increase monotonically relative to the intensities of the $\mathrm{S}_{2} \mathrm{O}_{7}{ }^{2-}$ bands, thereby indicating that all of the bands arise from one type of $\mathrm{Mo}^{\mathrm{VI}}$ complex. This is further justified by the lack of composition effects in the relative intensities of the bands ascribed to the complex. Furthermore, the bands due to the solvent $\mathrm{S}_{2} \mathrm{O}_{7}{ }^{2-}$ ion appear to diminish, indicating that the dissolution reaction takes place at the expense of $\mathrm{S}_{2} \mathrm{O}_{7}{ }^{2-}$ and results in the formation of one complex species, most likely according to eq 1 (see earlier). The bands due to the $\mathrm{Mo}^{\mathrm{VI}}$ complex predominate in the Raman spectra of molten mixtures with $X_{\mathrm{MoO}_{3}}^{0} \geq 0.25$. A small remainder of the main $\mathrm{S}_{2} \mathrm{O}_{7}{ }^{2-} 1085 \mathrm{~cm}^{-1}$ band can be 


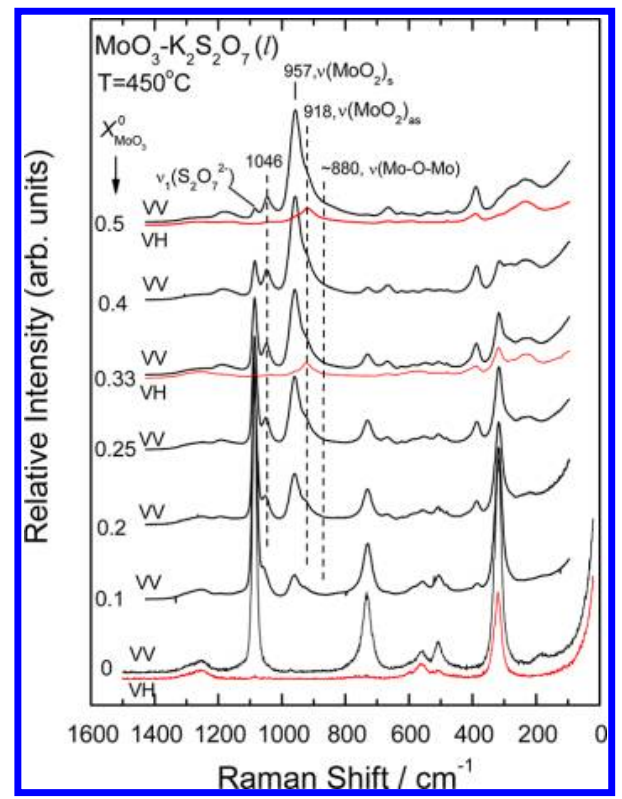

Figure 2. Raman spectra of molten $\mathrm{MoO}_{3}-\mathrm{K}_{2} \mathrm{~S}_{2} \mathrm{O}_{7}$ mixtures $(0<$ $\left.X_{\mathrm{MoO}_{3}}^{0}<0.50\right)$ in an oxygen atmosphere $\left(P_{\mathrm{O}_{2}}=0.2 \mathrm{~atm}\right)$ at $450{ }^{\circ} \mathrm{C}$. $X_{\mathrm{MoO}_{3}}^{0}$ denotes the mole fraction of $\mathrm{MoO}_{3}$. Laser wavelength, $\lambda_{0}=532$ $\mathrm{nm}$; laser power, $w=100 \mathrm{~mW}$; resolution, $2 \mathrm{~cm}^{-1}$.

Table 2. Raman Band Wavenumbers $\left(\mathrm{cm}^{-1}\right)$ and Assignments for Molybdenum(VI) Oxosulfato Complexes Formed in Molten $\mathrm{MoO}_{3}-\mathrm{K}_{2} \mathrm{~S}_{2} \mathrm{O}_{7} / \mathrm{O}_{2}(\mathrm{l})$ and $\mathrm{MoO}_{3}-$ $\mathrm{K}_{2} \mathrm{~S}_{2} \mathrm{O}_{7}-\mathrm{K}_{2} \mathrm{SO}_{4} / \mathrm{O}_{2}(\mathrm{l})$ Mixtures ${ }^{a}$

\begin{tabular}{|c|c|c|c|}
\hline \multicolumn{2}{|c|}{$\mathrm{MoO}_{3}-\mathrm{K}_{2} \mathrm{~S}_{2} \mathrm{O}_{7}(\mathrm{l})$ binary mixtures } & \multicolumn{2}{|c|}{$\begin{array}{c}\mathrm{MoO}_{3}-\mathrm{K}_{2} \mathrm{~S}_{2} \mathrm{O}_{7}-\mathrm{K}_{2} \mathrm{SO}_{4}(\mathrm{l}) \text { ternary } \\
\text { mixtures }\end{array}$} \\
\hline $\begin{array}{c}\text { band } \\
\text { location at } \\
450^{\circ} \mathrm{C}^{b} \\
\left(\mathrm{~cm}^{-1}\right)\end{array}$ & $\begin{array}{l}\text { tentative assignment for } \\
\mathrm{MoO}_{2}\left(\mathrm{SO}_{4}\right)_{2}^{2-}(1) \text { and } \\
{\left[\mathrm{MoO}_{2}\left(\mathrm{SO}_{4}\right)_{2}\right]_{n}^{2 n-}(1)}\end{array}$ & $\begin{array}{c}\text { band } \\
\text { location at } \\
635^{\circ} \mathrm{C} \\
\left(\mathrm{cm}^{-1}\right)\end{array}$ & $\begin{array}{l}\text { tentative assignment for } \\
\mathrm{MoO}_{2}\left(\mathrm{SO}_{4}\right)_{3}^{4-}(\mathrm{l}) \text { and } \\
{\left[\mathrm{MoO}_{2}\left(\mathrm{SO}_{4}\right)_{3}\right]_{n}{ }_{n}^{4 n-}(\mathrm{l})}\end{array}$ \\
\hline $\begin{array}{l}1270(w \\
\mathrm{dp})\end{array}$ & $\nu_{3}\left(\mathrm{SO}_{4}\right)$ & $\begin{array}{l}(1220) \\
\mathrm{dp})\end{array}$ & $\nu_{3}\left(\mathrm{SO}_{4}\right)$ \\
\hline $\begin{array}{l}1180(\mathrm{~m}, \\
\mathrm{p})\end{array}$ & $\nu_{3}\left(\mathrm{SO}_{4}\right)$ & & \\
\hline $\begin{array}{l}1155(w \\
\mathrm{dp})\end{array}$ & $\nu_{3}\left(\mathrm{SO}_{4}\right)$ & $\begin{array}{l}1175(\mathrm{~m}, \\
\mathrm{p})\end{array}$ & $\nu_{3}\left(\mathrm{SO}_{4}\right)$ \\
\hline $\begin{array}{l}1085(\mathrm{w} \\
\mathrm{p})\end{array}$ & $\nu_{1}\left(\mathrm{~S}_{2} \mathrm{O}_{7}\right)$ & & \\
\hline $1046(\mathrm{~s}, \mathrm{p})$ & $\nu_{1}\left(\mathrm{SO}_{4}\right)$ & $\begin{array}{l}1041(\mathrm{vs}, \\
\mathrm{p})\end{array}$ & $\nu_{1}\left(\mathrm{SO}_{4}\right)$ \\
\hline 957 (vs, p) & $\nu_{s}\left[\mathrm{Mo}(=\mathrm{O})_{2}\right]$ & $935(\mathrm{~s}, \mathrm{p})$ & $\nu_{\mathrm{s}}\left[\mathrm{Mo}(=\mathrm{O})_{2}\right]$ \\
\hline $918(\mathrm{~s}, \mathrm{dp})$ & $\nu_{\mathrm{as}}\left[\mathrm{Mo}(=\mathrm{O})_{2}\right]$ & $895(\mathrm{~s}, \mathrm{dp})$ & $\nu_{\mathrm{as}}\left[\mathrm{Mo}(=\mathrm{O})_{2}\right]$ \\
\hline $\begin{array}{l}\sim 880(\mathrm{br} \\
\mathrm{p} ?)^{c}\end{array}$ & $\nu(\mathrm{Mo}-\mathrm{O}-\mathrm{Mo})$ & & \\
\hline $664(\mathrm{~m}, \mathrm{p})$ & $\nu_{4}\left(\mathrm{SO}_{4}\right)$ & $657(s, p)$ & $\nu_{4}\left(\mathrm{SO}_{4}\right)$ \\
\hline $622(w, p)$ & $\nu_{4}\left(\mathrm{SO}_{4}\right)$ & $\begin{array}{l}600(\mathrm{~m} \\
\mathrm{dp})\end{array}$ & $\nu_{4}\left(\mathrm{SO}_{4}\right)$ \\
\hline $\begin{array}{l}590(w, \\
d p)\end{array}$ & $\nu_{4}\left(\mathrm{SO}_{4}\right)$ & & \\
\hline $540(w, p)$ & $\nu_{2}\left(\mathrm{SO}_{4}\right) ?$ & $498(\mathrm{~m}, \mathrm{p})$ & $\nu_{2}\left(\mathrm{SO}_{4}\right)$ \\
\hline $480(w, p ?)$ & $\nu_{2}\left(\mathrm{SO}_{4}\right)$ & $476(w, p)$ & $\nu_{2}\left(\mathrm{SO}_{4}\right)$ \\
\hline $389(\mathrm{~s}, \mathrm{p})$ & $\nu(\mathrm{Mo}-\mathrm{O})$ & $383(s, p)$ & $\nu(\mathrm{Mo}-\mathrm{O})$ \\
\hline $280(\mathrm{sh}, \mathrm{p})$ & & $273(\mathrm{~s}, \mathrm{p})$ & \\
\hline $236(\mathrm{~s}, \mathrm{dp})$ & $\nu_{\text {bending }}\left[\mathrm{Mo}(=\mathrm{O})_{2}\right]$ & $\begin{array}{l}230(\mathrm{~m} \\
\mathrm{dp})\end{array}$ & $\nu_{\text {bending }}\left[\mathrm{Mo}(=\mathrm{O})_{2}\right]$ \\
\hline
\end{tabular}

${ }^{a}$ Abbreviations: s, strong; m, medium; w, weak; br, broad; v, very; sh, shoulder; p, polarized; dp, depolarized. ${ }^{b}$ See Figure $2 .{ }^{c}$ Obscured band (see Figure 6). seen in the Raman spectrum obtained for the $X_{\mathrm{MoO}_{3}}^{0}=0.5$ sample, and the structural implications of this observation are discussed in a later section (vide infra).

The most prominent bands attributable to the $\mathrm{Mo}^{\mathrm{VI}}$ complex $\left(\mathrm{C}^{2 n-}\right)$ are the 1046,957 , and $389 \mathrm{~cm}^{-1}$ polarized bands and the $918 \mathrm{~cm}^{-1}$ depolarized band, the last of which can be discerned in the $\mathrm{VH}$ spectrum of the $X_{\mathrm{MoO}_{3}}^{0}=0.5$ sample displayed in Figure 2. Among these bands, the $957 \mathrm{~cm}^{-1}$ polarized band and the $918 \mathrm{~cm}^{-1}$ depolarized band occur in the $\mathrm{Mo}=\mathrm{O}$ stretching region. Interestingly, the occurrence of one polarized band and one depolarized band in the $\mathrm{Mo}=\mathrm{O}$ stretching region is, in principle, suggestive of a dioxo $\mathrm{O}=$ $\mathrm{Mo}=\mathrm{O}$ configuration. A dioxo $\mathrm{MO}_{2}(\mathrm{M}=$ transition metal $)$ unit has two stretching modes (both Raman-active), namely, a symmetric mode $\left(\nu_{\mathrm{s}}\right)$ and an antisymmetric mode $\left(\nu_{\mathrm{as}}\right)$, where the symmetric stretching mode exhibits a much higher Raman intensity and has a wavenumber that is $10-40 \mathrm{~cm}^{-1}$ higher compared to the corresponding vibrational properties of the antisymmetric mode. ${ }^{37}$ Moreover, in contrast to the $\nu_{\mathrm{s}}$ mode, which exhibits a polarized Raman band, the $\nu_{\text {as }}$ mode is depolarized, as expected. The wavenumbers, Raman intensities, and polarization properties of the 957 and $918 \mathrm{~cm}^{-1}$ bands constitute an exact match of the vibrational properties expected for a dioxo $\mathrm{Mo}^{\mathrm{VI}} \mathrm{O}_{2}{ }^{2+}$ unit and are therefore assigned as being due to the $\nu_{\mathrm{s}}$ and $\nu_{\mathrm{as}} \mathrm{Mo}(=\mathrm{O})_{2}$ stretching modes, respectively. Notably, $\mathrm{Mo}^{\mathrm{IV}} \mathrm{O}_{2}$ matrix-isolated molecules at $4 \mathrm{~K}$ exhibit the corresponding pair of $\nu_{\mathrm{s}} / \nu_{\mathrm{as}}$ modes at $948 / 899 \mathrm{~cm}^{-1}$, respectively, ${ }^{38}$ in good agreement with the $957 / 918 \mathrm{~cm}^{-1}$ counterparts observed in Figure 2 for the $\mathrm{MoO}_{2}{ }^{2+}$ core of the $\mathrm{Mo}^{\mathrm{VI}}$ complex. Measured wavenumbers of $\mathrm{Mo}=\mathrm{O}$ stretching vibrations, for mono-oxo and dioxo Mo model compounds of interest to the present study, are compiled in Table 3 (including references). Often, the gaseous transition-metal oxyhalides are used as models for predicting the vibrational positions of oxometallic functionalities. However, such a prediction is not straightforward because the ligand field (and the coordination) around the Mo atom is expected to affect the wavenumbers of the $\mathrm{Mo}(=\mathrm{O})_{2}$ entities. Thus, for compounds with comparable configurations, ligands with high electronegativity (e.g., halides) create an environment around the Mo atom that tends to strengthen the $\mathrm{Mo}=\mathrm{O}$ bond. This is in full conformity with the trends seen in Table 3 .

Among the rest of the observed bands due to the $\mathrm{Mo}^{\mathrm{VI}}$ complex, those located at wavenumbers higher than $450 \mathrm{~cm}^{-1}$ can be assigned to sulfate vibrational modes in environments of reduced symmetry due to coordination and/or bridging. The fundamentals for the ideal tetrahedral $T_{d}$ sulfate conformation span the irreducible representation

$$
\Gamma_{\mathrm{vib}}=\mathrm{A}_{1}\left(\nu_{1}\right)+\mathrm{E}\left(\nu_{2}\right)+2 \mathrm{~F}_{2}\left(\nu_{3}+\nu_{4}\right)
$$

Group theory predicts Raman activity for all modes, whereas only the $\mathrm{F}_{2}$ modes are infrared-allowed; modes labeled $\nu_{1}$ and $\nu_{3}$ are stretchings within the approximation of weak couplings, whereas modes $\nu_{2}$ and $\nu_{4}$ are bendings. Moreover, the "ideal" wavenumbers for the four fundamentals are known from Raman spectra of aqueous solutions: $\nu_{1}\left(\mathrm{~A}_{1}\right) \approx 980 \mathrm{~cm}^{-1}, \nu_{2}(\mathrm{E})$ $\approx 450 \mathrm{~cm}^{-1}, \nu_{3}\left(\mathrm{~F}_{2}\right) \approx 1100 \mathrm{~cm}^{-1}$, and $\nu_{4}\left(\mathrm{~F}_{2}\right) \approx 615 \mathrm{~cm}^{-1}$. ${ }^{37}$ However, symmetry alterations caused by coordination and bridging are expected to perturb the ideal behavior and give rise to band shifts, degeneracy lifts, and symmetry reduction of the sulfate modes. In particular, the terminal $\mathrm{S}-\mathrm{O}$ stretching of a coordinated $\mathrm{SO}_{4}$ moiety is expected to be blue-shifted, and 
Table 3. Mo $=\mathrm{O}$ Stretching Wavenumbers for Different Mono-Oxo and Dioxo Molybdenum Compounds

\begin{tabular}{|c|c|c|c|c|}
\hline compound & $\nu_{\mathrm{s}}\left[\mathrm{Mo}(=\mathrm{O})_{2}\right]^{a}\left(\mathrm{~cm}^{-1}\right)$ & $\nu_{\mathrm{as}}\left[\mathrm{Mo}(=\mathrm{O})_{2}\right]^{b}\left(\mathrm{~cm}^{-1}\right)$ & $\nu(\mathrm{Mo}=\mathrm{O})\left(\mathrm{cm}^{-1}\right)$ & $\operatorname{ref}(s)$ \\
\hline $\mathrm{M} o^{\mathrm{IV}} \mathrm{O}_{2}{ }^{c}$ & 948 & 899 & & 38 \\
\hline \multirow[t]{4}{*}{$\mathrm{MoO}_{2} \mathrm{Cl}_{2}$} & 994 & 972 & & 39 \\
\hline & 996 & 966 & & 40 \\
\hline & 997 & 971 & & 41 \\
\hline & $996^{d}$ & $968^{d}$ & & 42 \\
\hline $\mathrm{MoO}_{2} \mathrm{Br}_{2}$ & 995 & 970 & & 37 \\
\hline $\mathrm{MoO}_{2}\left(\mathrm{~L}^{n}\right) \mathrm{EtOH}$ & 937 & 902 & & 43 \\
\hline$\left[\mathrm{MoO}_{2}\left(\mathrm{SO}_{4}\right)_{2}\right]_{n}^{2 n-}$ & 957 & 918 & & this work \\
\hline$\left[\mathrm{MoO}_{2}\left(\mathrm{SO}_{4}\right)_{3}\right]_{n}^{4 n-}$ & 935 & 895 & & this work \\
\hline$\left[\mathrm{MoOCl}_{4}\right]^{-e}$ & & & 1008 & 37 \\
\hline $\mathrm{MoOCl}_{4}$ & & & 1015 & 37,39 \\
\hline \multirow[t]{2}{*}{$\mathrm{MoOF}_{4}$} & & & 1030 & 39 \\
\hline & & & 1050 & 37 \\
\hline $\mathrm{H}_{3} \mathrm{SiM}_{12} \mathrm{O}_{40}^{f}$ & & & 1006 & 44 \\
\hline$\left(\mathrm{MoO}_{x}\right)_{n} / \mathrm{TiO}_{2}$ & & & 994 & 29,30 \\
\hline$\left(\mathrm{MoO}_{x}\right)_{n} / \mathrm{ZrO}_{2}$ & & & $985-995^{g}$ & 27 \\
\hline$\left(\mathrm{MoO}_{x}\right)_{n} / \mathrm{Al}_{2} \mathrm{O}_{3}$ & & & $994-1002^{g}$ & 27 \\
\hline
\end{tabular}

${ }^{a}$ Symmetric stretching. ${ }^{b}$ Antisymmetric stretching. ${ }^{c}$ In a neon matrix $(4 \mathrm{~K}) .{ }^{d} \mathrm{In}$ a $\mathrm{N}_{2}$ matrix. ${ }^{e} \mathrm{Mo}(\mathrm{IV}) .{ }^{f}$ Keggin cluster, containing mono-oxo Mo= $\mathrm{O}$ units. ${ }^{g}$ Depending on Mo loading.

therefore, the $1046 \mathrm{~cm}^{-1}$ polarized band can be assigned to the respective mode of a coordinated $\mathrm{SO}_{4}{ }^{2-}$ group (see Table 2). Bands due to the $\mathrm{Mo}^{\mathrm{VI}}$ complex with wavenumbers below 450 $\mathrm{cm}^{-1}$ are assigned either to $\mathrm{Mo}(=\mathrm{O})_{2}$ bendings or to $\mathrm{Mo}-\mathrm{O}$ modes [not belonging to the $\mathrm{Mo}(=\mathrm{O})_{2}$ core that also exhibits the $957 / 918 \mathrm{~cm}^{-1}$ symmetric and antisymmetric counterpart modes] within the coordination sphere around Mo.

Stoichiometry of the Movi Complex in the Binary $\mathrm{MoO}_{3}-\mathrm{K}_{2} \mathrm{~S}_{2} \mathrm{O}_{7}$ System. The above preliminary assignment of the $957 \mathrm{~cm}^{-1}$ polarized band and the $918 \mathrm{~cm}^{-1}$ depolarized band as being due to the $\nu_{\mathrm{s}}$ and $\nu_{\mathrm{as}}$ modes, respectively, of a dioxo $\mathrm{MoO}_{2}{ }^{2+}$ unit and the observation of one single polarized band in the $\mathrm{S}-\mathrm{O}$ terminal stretching region $\left(1046 \mathrm{~cm}^{-1}\right)$ is adequate for inferring that the $\mathrm{Mo}^{\mathrm{VI}}$ complex formed according to eq 1 consists of $\mathrm{MoO}_{2}{ }^{2+}$ and $\mathrm{SO}_{4}{ }^{2-}$ units. The determination of the stoichiometry of reaction 1 from the Raman data (e.g., Figure 2) is based on the application of a procedure ${ }^{1,5}$ that correlates the relative Raman band intensities with the stoichiometric coefficient, $n$. Reaction 1 is assumed to be complete (i.e., $\mathrm{MoO}_{3}$ is completely dissolved), and each equilibrium mixture is assumed to consist of the complex species formed, $\mathrm{C}^{2 n-}$, and the remainder of the $\mathrm{S}_{2} \mathrm{O}_{7}{ }^{2-}$. The basic concept of the method originates from the theory of vibrational Raman scattering from an assembly of randomly oriented molecules, for which detailed derivations and formulas can be found in ref 45 . For the purpose of the present analysis, we note that the measured integrated Raman intensity due to a vibrational fundamental $\nu(i)$ of species $j, I_{j, \nu(i)}$, is directly related to the number of moles of species $j, N_{j}$, contained in the scattering volume according to

$$
I_{j, \nu(i)}=A \frac{1}{f[\nu(i), T]} N_{j}
$$

where $f[\nu(i), T]$ is the Boltzmann thermal population factor

$$
f[\nu(i), T]=1-\exp \left[-\frac{h c \nu(i)}{k T}\right]
$$

which disentangles the experimentally measured Raman intensities from temperature effects. Factors including molec- ular scattering properties, excitation laser wavelength, and instrumental response are embodied in the parameter $A$. For determining the stoichiometry, $n$, we note that the intensity quotient

$$
I^{0}=\frac{\left\{I_{\mathrm{S}_{2} \mathrm{O}_{7}{ }^{2-}, \nu\left(\mathrm{S}_{2} \mathrm{O}_{7}{ }^{2-}\right)} f\left[\nu\left(\mathrm{S}_{2} \mathrm{O}_{7}{ }^{2-}\right), T\right]\right\} / N_{\mathrm{eq}, \mathrm{S}_{2} \mathrm{O}_{7}{ }^{2-}}}{\left\{I_{\mathrm{C}^{2 n-}, \nu\left(\mathrm{C}^{2 n-}\right)} f\left[\nu\left(\mathrm{C}^{2 n-}\right), T\right]\right\} / N_{\mathrm{eq}, \mathrm{C}^{2 n-}}}
$$

expressing the ratio of the scattering power per ion of $\mathrm{S}_{2} \mathrm{O}_{7}{ }^{2-}$ to the scattering power per ion of $\mathrm{C}^{2 n-}$ should be a universal constant independent of cell composition and total amounts of

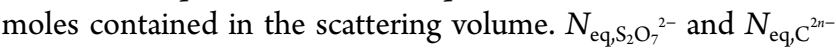
are the numbers of moles of the components $\mathrm{S}_{2} \mathrm{O}_{7}{ }^{2-}$ and $\mathrm{C}^{2 n-}$ present in each final equilibrium mixture. Now, if one assumes that eq 1 is the only stoichiometric process taking place,

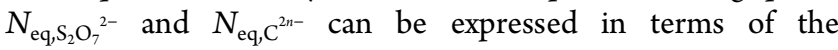
stoichiometry as

$$
\begin{aligned}
& N_{\text {eq, } \mathrm{S}_{2} \mathrm{O}_{7}{ }^{2-}}=N_{\mathrm{S}_{2} \mathrm{O}_{7}{ }^{2-}-n N_{\mathrm{MoO}_{3}}^{0}} \\
& N_{\text {eq, } \mathrm{C}^{2 n-}}=N_{\mathrm{MoO}_{3}}^{0}
\end{aligned}
$$

Therefore, it turns out that, if a correct choice of $n$ is made, eq 3

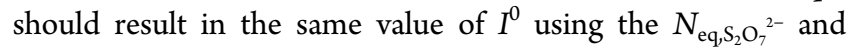
$N_{\text {eq, }} \mathrm{C}^{2 n-}$ values computed for each initial composition together with the Raman intensity data from each corresponding cell. Although it is immaterial which particular band represents each species, it is preferable that bands due to symmetric modes that do not overlap with other bands be chosen. As a general rule, the band choice should pertain to strong, sharp, symmetric, and polarized bands.

Six binary $\mathrm{MoO}_{3}-\mathrm{K}_{2} \mathrm{~S}_{2} \mathrm{O}_{7}$ mixtures were prepared (cells 2-7 in Table 1), and the Raman spectra of the corresponding melts were recorded under static equilibrium (Figure 2). The 957 $\mathrm{cm}^{-1}$ band due to symmetric $\mathrm{Mo}(=\mathrm{O})_{2}$ stretching was chosen as representative of the $\mathrm{Mo}^{\mathrm{VI}}$ complex $\left(\mathrm{C}^{2 n-}\right)$, and the 1085 $\mathrm{cm}^{-1}$ symmetric stretching was chosen as representative of $\mathrm{S}_{2} \mathrm{O}_{7}{ }^{2-}$. The integrated Raman intensities (peak areas) were then measured for each cell. The pertinent data are compiled in Table S1 (Supporting Information). $I^{0}$ was then computed for 
four parametric choices for $n$ (i.e., $n=0.5,1,1.5$, and 2) for all six mixtures, as summarized in Table S2 (Supporting Information). Figure 3 shows plots of the $I^{0}$ quotient as a

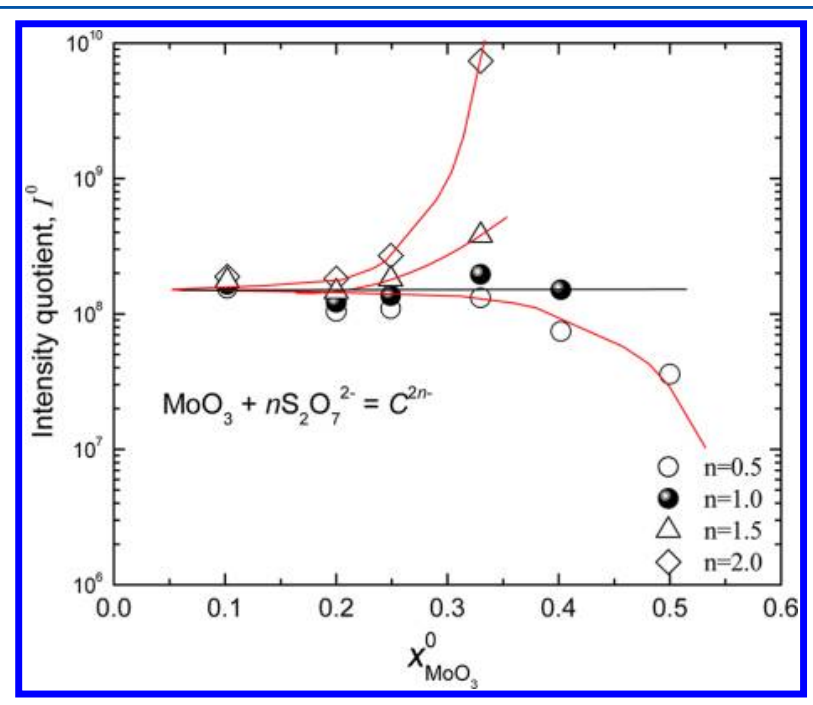

Figure 3. Plot of the intensity quotient, $I^{0}$, for four assumed values of the stoichiometric coefficient, $n$.

function of $X_{\mathrm{MoO}_{3}}^{0}$ for the four choices of $n$. The correct value of $n$ giving rise to a constant value for $I^{0}$ is obviously $n=1$, as illustrated by the horizontal line in Figure 3 . Thus, the product formula of reaction 1 is $\mathrm{MoS}_{2} \mathrm{O}_{10}{ }^{2-}$. A plausible structural interpretation is that the $\mathrm{Mo}^{\mathrm{VI}}$ complex contains a $\mathrm{MoO}_{2}{ }^{2+}$ core and coordinated $\mathrm{SO}_{4}{ }^{2-}$ ligands in accordance with the following simplest form for reaction 1

$$
\mathrm{MoO}_{3}+\mathrm{S}_{2} \mathrm{O}_{7}{ }^{2-} \rightarrow \mathrm{MoO}_{2}\left(\mathrm{SO}_{4}\right)_{2}{ }^{2-}
$$

Although the results shown in Figure 3 are based on the Raman spectra obtained for the molten $\mathrm{MoO}_{3}-\mathrm{K}_{2} \mathrm{~S}_{2} \mathrm{O}_{7}$ mixtures at 450
${ }^{\circ} \mathrm{C}$, the same value for the stoichiometry $(n=1)$ was found using the spectral data obtained at 400,550 , and $640{ }^{\circ} \mathrm{C}$ (results not shown). Therefore, reaction 6 must be the stoichiometric process taking place in the temperature range of $400-640{ }^{\circ} \mathrm{C}$. However, it should be regarded only as a scheme accounting for the formation of the $\mathrm{MoO}_{2}\left(\mathrm{SO}_{4}\right)_{2}{ }^{2-}$ unit, which should occur only as a monomer in dilute melts, whereas associated polymeric $\left[\mathrm{MoO}_{2}\left(\mathrm{SO}_{4}\right)_{2}\right]_{m}{ }^{2 m-}$ units and/or three-dimensional $\left[\mathrm{MoO}_{2}\left(\mathrm{SO}_{4}\right)_{2}\right]_{m}{ }^{2 m-}$ networks are expected to be formed for increasing $X_{\mathrm{MoO}_{3}}^{0}$. In the same context, it should be noted that melts with $X_{\mathrm{MoO}_{3}}^{0} \geq 0.2$ exhibit high viscosity and glass-forming ability upon quenching.

Structural Models for $\mathrm{MoO}_{2}\left(\mathrm{SO}_{4}\right)_{2}{ }^{2-}$ and $\left[\mathrm{MoO}_{2}\left(\mathrm{SO}_{4}\right)_{2}\right]_{m}{ }^{2 m-}$ : Structural Alterations upon Heating. Taking into account the fact that the $\mathrm{Mo}^{\mathrm{VI}}$ complex consists of a dioxo $\mathrm{MoO}_{2}{ }^{2+}$ core and two coordinated sulfate groups, it turns out that the simplest and most plausible structural model for $\mathrm{MoO}_{2}\left(\mathrm{SO}_{4}\right)_{2}{ }^{2-}$ is the one shown in Figure 4A, involving hexa coordination for Mo in conformity with its coordination chemistry. The Mo atom is located in the center of a $\mathrm{MoO}_{6}$ (distorted) octahedron, of which the apical and one equatorial position are occupied by two oxide ligands forming a bent dioxo $\mathrm{MoO}_{2}{ }^{2+}$ unit, whereas the remaining four positions of the first coordination sphere are occupied by the two bidentate chelating sulfates. One bidentate chelate sulfate group is coordinated to the equatorial plane, and the other is coordinated to the remaining axial and equatorial vertexes of the octahedron. However, it is known that transition-metal oxosulfato complexes tend to associate to each other through bridging bidentate sulfate groups, forming chainlike or networklike polymeric anionic complexes. ${ }^{1-3,7,8,46-49}$ It is evident that the extent of association of $\mathrm{MoO}_{2}\left(\mathrm{SO}_{4}\right)_{2}{ }^{2-}$ units is favored with increasing $X_{\mathrm{MoO}_{3}}^{0}$. Figure $4 \mathrm{~B}$ shows possible alternative structural models for the $\left[\mathrm{MoO}_{2}\left(\mathrm{SO}_{4}\right)_{2}\right]_{m}^{2 m-}$ chains and/or networks. The association between adjacent $\mathrm{MoO}_{2}{ }^{2+}$ cores can take place either by single bidentate bridging sulfate

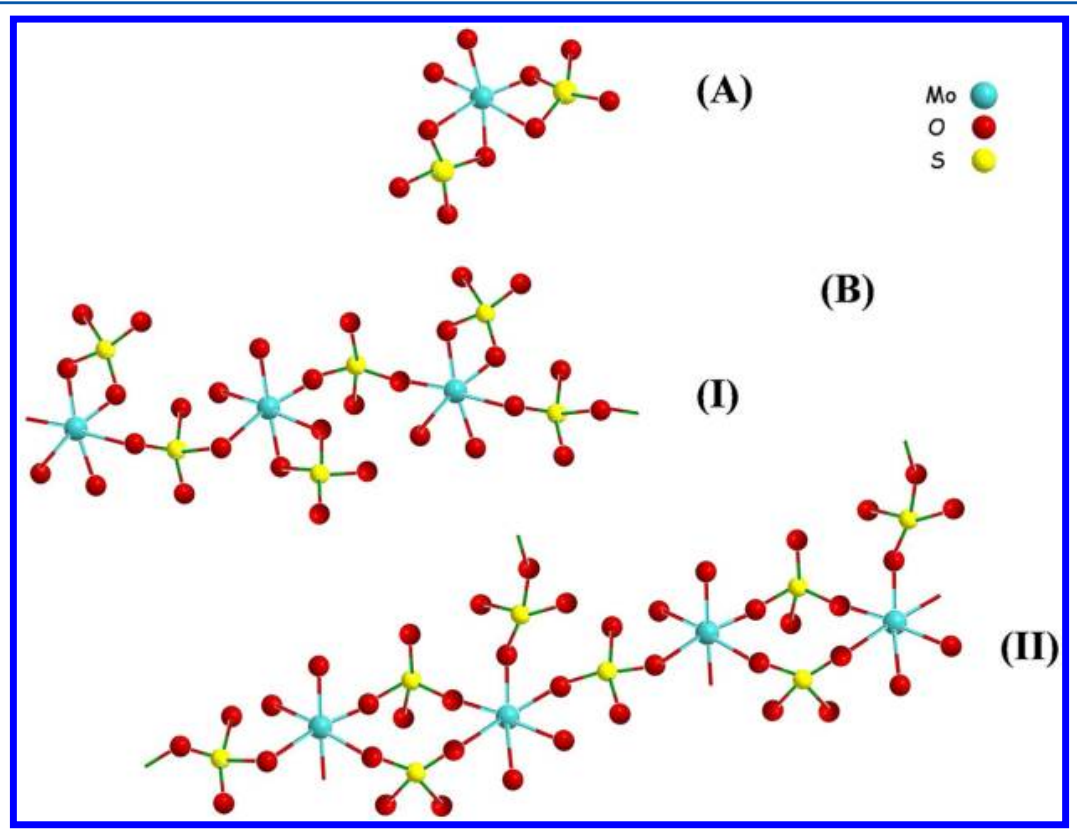

Figure 4. (A) Plausible structural model for the monomeric $\mathrm{MoO}_{2}\left(\mathrm{SO}_{4}\right)_{2}{ }^{2-}$ complex with two chelate sulfate groups. (B) Alternative structural models for associated/polymeric $\left[\mathrm{MoO}_{2}\left(\mathrm{SO}_{4}\right)_{2}\right]_{m}{ }^{2 m-}$ species. Model I involves one bridging sulfate and one bidentate chelating sulfate per Mo. Model II involves molybdenum chains connected by both double and single bridging sulfates. 
groups, giving rise to the formation of chains (model I in Figure $4 \mathrm{~B}$ ), or by double bidentate bridging sulfates, thereby enabling the three-dimensional growth of the polymers formed (model II in Figure 4B). As shown in Figure 4B, within structural model II, it is possible that two adjacent $\mathrm{MoO}_{2}{ }^{2+}$ cores share two bidentate bridging sulfates, thereby forming a double sulfate bridge. The types of sulfate groups participating in structural models I and II (Figure 4B) include bidentate bridging (models I and II) and bidentate chelating groups (model I) with similar local symmetries, thereby justifying the moderate splitting of the degenerate $\nu_{2}, \nu_{3}$, and $\nu_{4}$ sulfate modes observed in the Raman spectra of Figure 2.

We now focus on an interesting composition and temperature effect. From the context of the discussion on the stoichiometry of the $\mathrm{Mo}^{\mathrm{VI}}$ complex, it turns out that a $1: 1$ $\mathrm{MoO}_{3}-\mathrm{K}_{2} \mathrm{~S}_{2} \mathrm{O}_{7}$ (i.e., $X_{\mathrm{MoO}_{3}}^{0}=0.50$ ) molten mixture would react stoichiometrically $\left(m \mathrm{MoO}_{3}+m \mathrm{~S}_{2} \mathrm{O}_{7}{ }^{2-} \rightarrow\left[\mathrm{MoO}_{2}\left(\mathrm{SO}_{4}\right)_{2}\right]_{m}{ }^{2 m-}\right)$ with complete consumption of the pyrosulfate. However, as seen in the Raman spectrum obtained for the $X_{\mathrm{MoO}_{3}}^{0}=0.50$ sample at $450{ }^{\circ} \mathrm{C}$ (Figure 2) the characteristic $1085 \mathrm{~cm}^{-1}$ $\mathrm{S}_{2} \mathrm{O}_{7}^{2-}$ band persists, thereby attesting to the presence of a small amount of $\mathrm{S}_{2} \mathrm{O}_{7}{ }^{2-}$, despite the complete consumption of $\mathrm{MoO}_{3}$. An inspection (Figure 5) of the temperature depend-

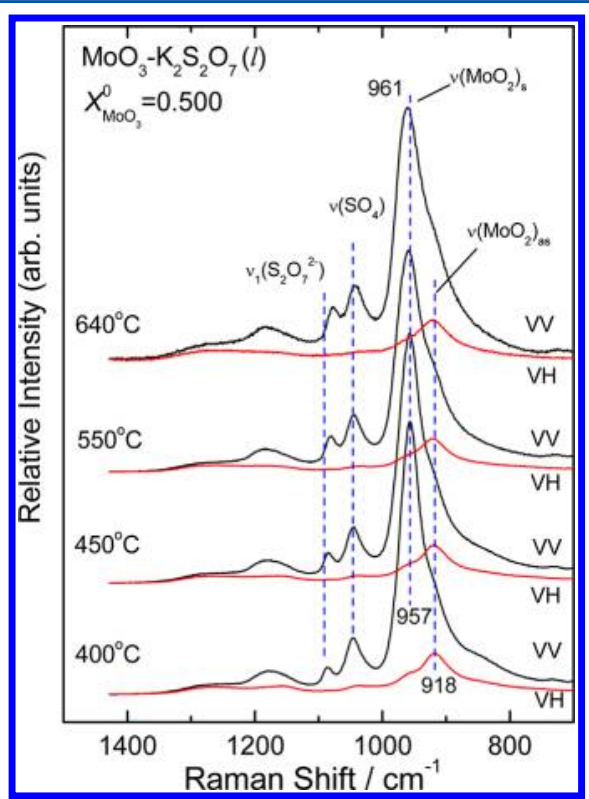

Figure 5. Temperature dependence of Raman spectra obtained for molten $\mathrm{MoO}_{3}-\mathrm{K}_{2} \mathrm{~S}_{2} \mathrm{O}_{7}$ mixtures with $X_{\mathrm{MoO}_{3}}^{0}=0.50$ in an oxygen atmosphere $\left(P_{\mathrm{O}_{2}}=0.2 \mathrm{~atm}\right)$. For spectrum recording parameters, see the caption of Figure 2.

ence (in the range of $400-640{ }^{\circ} \mathrm{C}$ ) of the Raman spectra for the $X_{\mathrm{MoO}_{3}}^{0}=0.50$ sample in the stretching vibrational wavenumber region reveals that the relative intensity of the $\mathrm{S}_{2} \mathrm{O}_{7}{ }^{2-}$ band increases with increasing temperature. Furthermore, as seen in Figure 5 , the $957 / 918 \mathrm{~cm}^{-1} \mathrm{MoO}_{2} \nu_{\mathrm{s}} / \nu_{\text {as }}$ stretching feature broadens, developing a low-frequency wing, and undergoes a $\sim 4 \mathrm{~cm}^{-1}$ blue shift with increasing temperature. Actually, the $4 \mathrm{~cm}^{-1}$ blue shift is essentially much more significant if one takes into account the fact that, in the absence of other effects, a red shift would be expected with increasing temperature because of Boltzmann distribution factors and the closer packing of thermally excited vibrational levels. Indeed, contrary to the $\nu_{\mathrm{s}} / \nu_{\text {as }}$ feature (blue shifting by $\sim 4 \mathrm{~cm}^{-1}$ ), the corresponding $\mathrm{S}_{2} \mathrm{O}_{7}{ }^{2-}$ and $\mathrm{SO}_{4}{ }^{2-}$ bands are redshifted by 8 and $6 \mathrm{~cm}^{-1}$, respectively. Upon deconvolution of the pertinent spectral envelope (Figure 6), a broad band

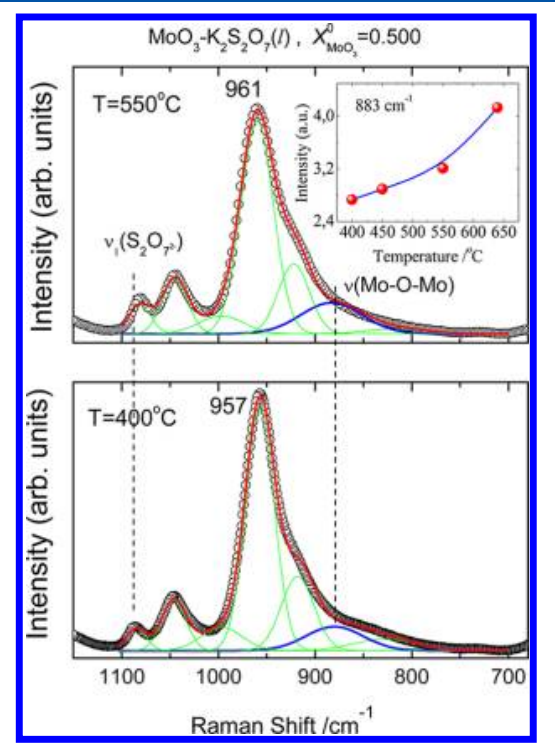

Figure 6. Temperature dependence of deconvoluted polarized (VV) Raman spectra obtained for molten $\mathrm{MoO}_{3}-\mathrm{K}_{2} \mathrm{~S}_{2} \mathrm{O}_{7}$ mixtures with $X_{\mathrm{MoO}_{3}}^{0}=0.50$ in an oxygen atmosphere $\left(P_{\mathrm{O}_{2}}=0.2 \mathrm{~atm}\right)$. Open circles, experimental data (only $20 \%$ of the points are shown for clarity); thick solid red line, total fit curve; thin green lines, individual modes modeled by Gaussian functions; thick blue solid line, $883 \mathrm{~cm}^{-1}$ mode, assigned to $\mathrm{Mo}-\mathrm{O}-\mathrm{Mo}$ functionalities. Inset: Temperature dependence of the $883 \mathrm{~cm}^{-1}$ band intensity. For spectrum recording parameters, see the caption of Figure 2 .

appears at $\sim 880 \mathrm{~cm}^{-1}$, and its intensity increases with increasing temperature (see Figure 6 inset). The observations are interpreted to indicate that, with increasing temperature, an equilibrium shift takes place, resulting in release of $\mathrm{S}_{2} \mathrm{O}_{7}{ }^{2-}$ together with a slight structural alteration in the coordination around Mo that that tends to strengthen the $\mathrm{Mo}(=\mathrm{O})_{2}$ bonds slightly. Now, taking into account that the ca. $880 \mathrm{~cm}^{-1}$ broad band (Figure 6) lies in the expected region for $\mathrm{Mo}-\mathrm{O}-\mathrm{Mo}$ functionalities, ${ }^{27,29,30}$ a scenario accounting for all of the above observations is proposed in Figure 7, as follows. With increasing temperatures, cleavage of the double bidentate sulfate bridge takes place, resulting in detachment of a $\mathrm{S}_{2} \mathrm{O}_{7}{ }^{2-}$ moiety and creation of a Mo-O-Mo bridge and a simultaneous "defect" in the coordination number of Mo, that is locally lowered from 6 to 5 in a pseudo-octahedral arrangement, thereby accounting for a slight strengthening of the bond order within the $\mathrm{Mo}(=\mathrm{O})_{2}$ unit. The effect takes place exclusively in melts with $X_{\mathrm{MoO}_{3}}^{0}$ equal to or slightly lower than 0.50 , because an excess of $\mathrm{S}_{2} \mathrm{O}_{7}{ }^{2-}$ (i.e., for $X_{\mathrm{MoO}_{3}}^{0} \leq 0.40$ ) would shift the scenario shown in Figure 7 to the left. Seen from a different angle, if the complete conversion had taken place in a $1: 1 \quad \mathrm{MoO}_{3}-\mathrm{K}_{2} \mathrm{~S}_{2} \mathrm{O}_{7}$ (i.e., $X_{\mathrm{MoO}_{3}}^{0}=0.50$ ) molten mixture, it would be possible for the free energy of the system to fall to an even lower value, if some of the $\mathrm{Mo}^{\mathrm{VI}}$ complex formed were to dissociate according to the scheme in Figure 7, on account of the free energy of mixing of the species formed as a result of the proposed dissociation. 


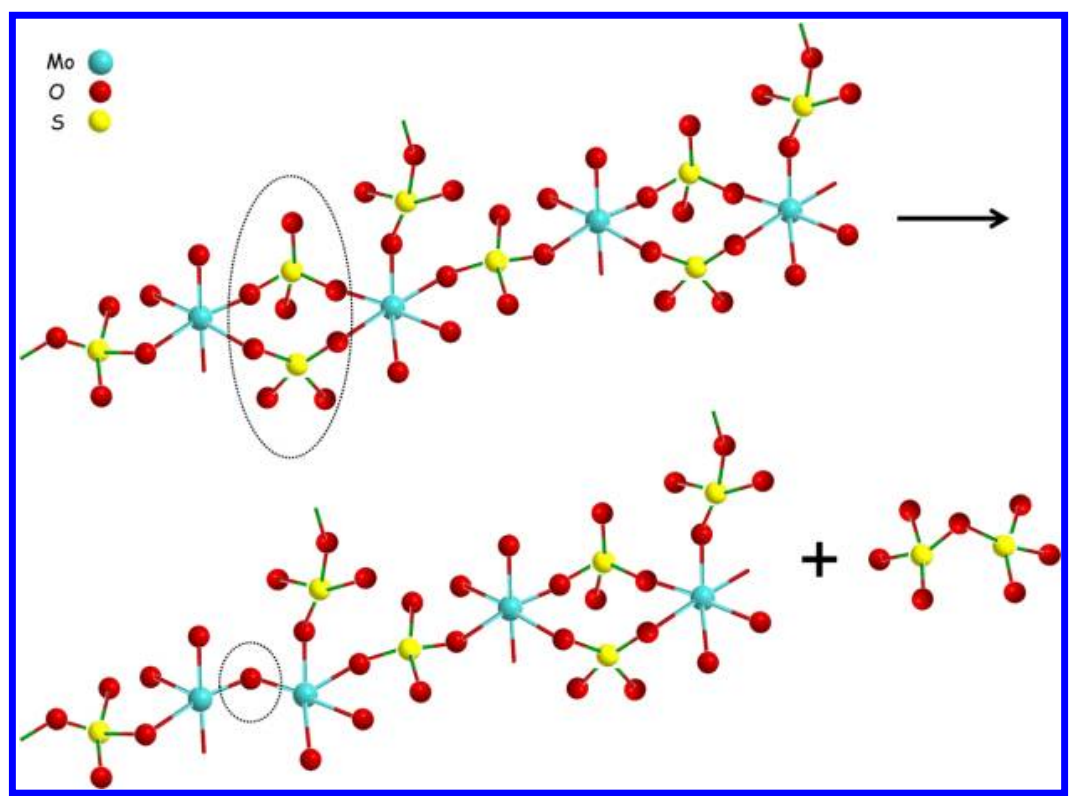

Figure 7. Molecular scenario for the temperature-dependent partial dissociation evidenced in the Raman spectra shown in Figures 5 and 6 . The ellipse shows a double sulfate bridge that is replaced by an oxide bridge.

The first part of Table 2 compiles the detailed band assignments, together with the intensity and polarization characteristics in accordance with the structural model proposed for the $\mathrm{MoO}_{2}\left(\mathrm{SO}_{4}\right)_{2}{ }^{2-}$ complex.

Raman Spectra of Ternary $\mathrm{MoO}_{3}-\mathrm{K}_{2} \mathrm{~S}_{2} \mathrm{O}_{7}-\mathrm{K}_{2} \mathrm{SO}_{4}$ Molten Mixtures. During the equilibration of the ternary $\mathrm{MoO}_{3}-\mathrm{K}_{2} \mathrm{~S}_{2} \mathrm{O}_{7}-\mathrm{K}_{2} \mathrm{SO}_{4}$ mixtures that took place in transparent tube furnaces, it was found that $\mathrm{K}_{2} \mathrm{SO}_{4}$ could be dissolved in substantial amounts. The constituents of cells 8, 9, 11, and 12 (Table 1 and Figure 1) with $X_{\mathrm{MoO}_{3}}^{0}=0.20$ and 0.25 melted readily at $500{ }^{\circ} \mathrm{C}$, resulting in yellow to dark yellow liquids, whereas heating at higher temperatures was necessary to obtain transparent dark yellow to brownish yellow molten mixtures in cells $14,15,17$, and 18 . The mixtures contained in cells 14 and 15 with $X_{\mathrm{MoO}_{3}}^{0}=0.33$ were molten at $550{ }^{\circ} \mathrm{C}$, and heating to $580-600{ }^{\circ} \mathrm{C}$ was adequate for melting the contents of cells 17 and 18 with $X_{\mathrm{MoO}_{3}}^{0}=0.50$. A white solid excess was present in cells 10,13,16, and 19 despite persistent heating and torching of the samples, indicating that the particular cells contain, as explained below, excess $\mathrm{K}_{2} \mathrm{SO}_{4}$. Figures 8-10 show "titrationlike” series of Raman spectra obtained for mixtures with $X_{\mathrm{MoO}_{3}}^{0}$ $=0.25$ (Figure 8), $X_{\mathrm{MoO}_{3}}^{0}=0.33$ (Figure 9), and $X_{\mathrm{MoO}_{3}}^{0}=0.50$ (Figure 10) as a function of the ratio of number of moles of $\mathrm{SO}_{4}{ }^{2-}$ added per Mo atom, $\mathrm{Y}=n\left(\mathrm{SO}_{4}{ }^{2-}\right) / n(\mathrm{Mo})$. All figures contain, for comparison, the Raman spectra of pure molten $\mathrm{K}_{2} \mathrm{~S}_{2} \mathrm{O}_{7}$ and molten $\mathrm{K}_{2} \mathrm{~S}_{2} \mathrm{O}_{7}-\mathrm{K}_{2} \mathrm{SO}_{4}$ (saturated).

A number of gradual changes (discussed below) take place in the Raman spectra of $\mathrm{MoO}_{3}-\mathrm{K}_{2} \mathrm{~S}_{2} \mathrm{O}_{7}$ (i.e., $Y=0$ ) melts upon the incremental addition/dissolution of $\mathrm{K}_{2} \mathrm{SO}_{4}$. Interestingly, the gradual changes definitively terminate for $Y=n\left(\mathrm{SO}_{4}{ }^{2-}\right)$ / $n(\mathrm{Mo})=1$. In particular, the following observations were made:

(1) The $957 / 918 \mathrm{~cm}^{-1} \nu_{\mathrm{s}} / \nu_{\text {as }}$ pair due to the stretching modes of $\mathrm{Mo}(=\mathrm{O})_{2}$ is shifted to $935 / 895 \mathrm{~cm}^{-1}$ on going from $Y=0$ (i.e., no sulfate added) to $Y=1$ (best seen in Figure 10 by comparing spectra $c$ and e). Still, the wavenumber, intensity, and polarization characteristics of the resulting $935 / 895 \mathrm{~cm}^{-1}$ pair are in full conformity

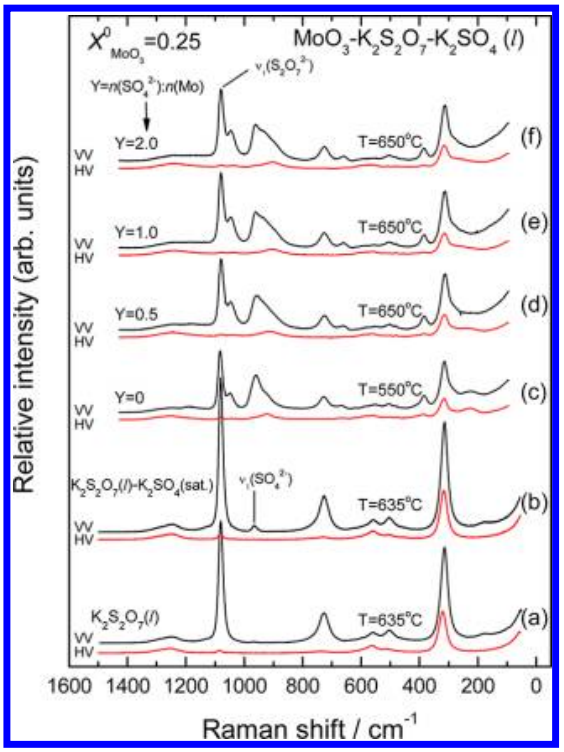

Figure 8. Titrationlike series of Raman spectra obtained under an oxygen atmosphere $\left(P_{\mathrm{O}_{2}}=0.2 \mathrm{~atm}\right)$ for molten $\mathrm{MoO}_{3}-\mathrm{K}_{2} \mathrm{~S}_{2} \mathrm{O}_{7}-$ $\mathrm{K}_{2} \mathrm{SO}_{4}$ mixtures with $\mathrm{X}_{\mathrm{MoO}_{3}}^{0}=0.25$ and incremental presence of $\mathrm{K}_{2} \mathrm{SO}_{4}$ $(0 \leq Y \leq 2)$ and temperatures as indicated by each spectrum. $X_{\mathrm{MoO}_{3}}^{0}$ denotes the formal mole fraction of $\mathrm{MoO}_{3}$ in the binary $\mathrm{MoO}_{3}-$ $\mathrm{K}_{2} \mathrm{~S}_{2} \mathrm{O}_{7}$ mixture. For spectrum recording parameters, see the caption of Figure 2 .

with its assignment as being due to the respective $\nu_{\mathrm{s}} / \nu_{\mathrm{as}}$ modes of a dioxo $\mathrm{MoO}_{2}{ }^{2+}$ core, which apparently is still present in the $\mathrm{Mo}^{\mathrm{VI}}$ complex, although in a slightly different coordination environment that appears to weaken the $\mathrm{Mo}=\mathrm{O}$ bonding.

(2) The $\mathrm{S}-\mathrm{O}$ terminal stretching due to the coordinated $\mathrm{SO}_{4}$ groups of the $\left[\mathrm{MoO}_{2}\left(\mathrm{SO}_{4}\right)_{2}\right]_{m}{ }^{2 m-}$ complex (spectra $\mathrm{c}$ in Figures 8-10) gains intensity (relative to the $\nu_{\mathrm{s}} / \nu_{\mathrm{as}}$ doublet, for example) upon $\mathrm{K}_{2} \mathrm{SO}_{4}$ addition/dissolution up to $Y=1$ and undergoes a red shift from 1046 to 1041 $\mathrm{cm}^{-1}$ (compare spectra e to spectra $\mathrm{c}$ in Figures 8-10). 


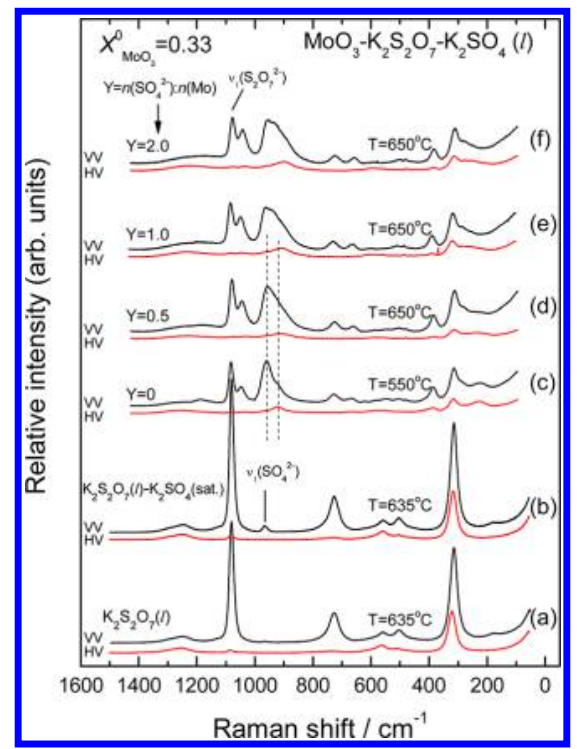

Figure 9. Titrationlike series of Raman spectra obtained under an oxygen atmosphere $\left(P_{\mathrm{O}_{2}}=0.2 \mathrm{~atm}\right)$ for molten $\mathrm{MoO}_{3}-\mathrm{K}_{2} \mathrm{~S}_{2} \mathrm{O}_{7}-$ $\mathrm{K}_{2} \mathrm{SO}_{4}$ mixtures with $X_{\mathrm{MoO}_{3}}^{0}=0.33$ and incremental presence of $\mathrm{K}_{2} \mathrm{SO}_{4}$ $(0 \leq Y \leq 2)$ and temperatures as indicated by each spectrum. $X_{\mathrm{MoO}_{3}}^{0}$ denotes the formal mole fraction of $\mathrm{MoO}_{3}$ in the binary $\mathrm{MoO}_{3}-$ $\mathrm{K}_{2} \mathrm{~S}_{2} \mathrm{O}_{7}$ mixture. For spectrum recording parameters, see the caption of Figure 2.

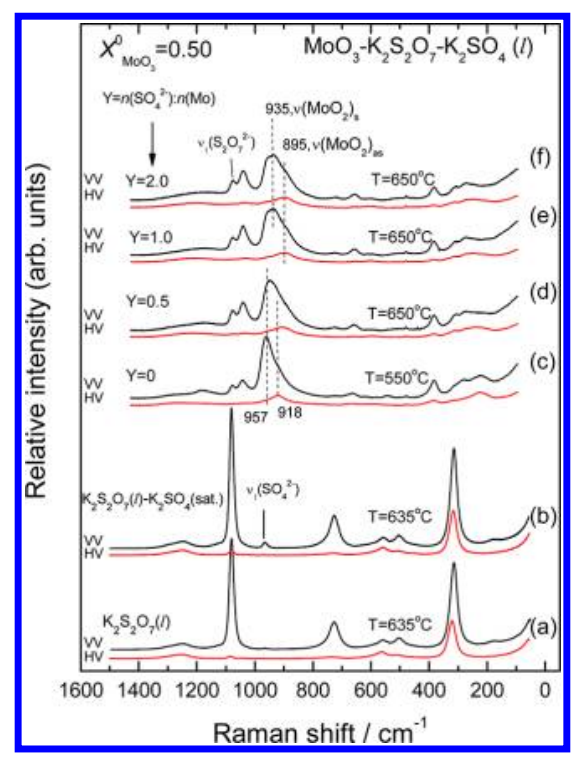

Figure 10. Titrationlike series of Raman spectra obtained under an oxygen atmosphere $\left(P_{\mathrm{O}_{2}}=0.2 \mathrm{~atm}\right)$ for molten $\mathrm{MoO}_{3}-\mathrm{K}_{2} \mathrm{~S}_{2} \mathrm{O}_{7}-$ $\mathrm{K}_{2} \mathrm{SO}_{4}$ mixtures with $X_{\mathrm{MoO}_{3}}^{0}=0.50$ and incremental presence of $\mathrm{K}_{2} \mathrm{SO}_{4}$ $(0 \leq Y \leq 2)$ and temperatures as indicated by each spectrum. $X_{\mathrm{MoO}_{3}}^{0}$ denotes the formal mole fraction of $\mathrm{MoO}_{3}$ in the binary $\mathrm{MoO}_{3}-$ $\mathrm{K}_{2} \mathrm{~S}_{2} \mathrm{O}_{7}$ mixture. For spectrum recording parameters, see the caption of Figure 2.

This is interpreted to indicate that more sulfate groups (actually one more $\mathrm{SO}_{4}$ per $\mathrm{Mo}$ ) are involved in the first coordination sphere of Mo.

(3) The $965 \mathrm{~cm}^{-1} v_{1}\left(\mathrm{SO}_{4}{ }^{2-}\right)$ band appears in all Raman spectra of ternary mixtures with $Y=0.5$ and $Y=1$ (Figures 8-10), because $\mathrm{K}_{2} \mathrm{SO}_{4}$ has a finite solubility in molten $\mathrm{K}_{2} \mathrm{~S}_{2} \mathrm{O}_{7}$, as judged also by comparing, for example, spectra labeled $\mathrm{a}$ and $\mathrm{b}$ in Figures 8-10. Significantly, with increasing $X_{\mathrm{MoO}_{3}}^{0}$, this band becomes less prominent (spectra $d$ and e in Figure 9) and/or is hardly seen (spectra $d$ and e in Figure 10) because of the much lower available amounts of free $\mathrm{S}_{2} \mathrm{O}_{7}{ }^{2-}$ and the subsequent lower capacity for "physically" dissolving $\mathrm{SO}_{4}{ }^{2-}$.

(4) Excess added $\mathrm{K}_{2} \mathrm{SO}_{4}$ (i.e., $Y=2$ ) results in precipitation of $\mathrm{K}_{2} \mathrm{SO}_{4}$ in the form of a white "cloud" in the bottom of the cell. The characteristic $v_{1}\left(\mathrm{SO}_{4}{ }^{2-}\right)$ band at $965 \mathrm{~cm}^{-1}$ is seen in spectra $f$ of Figures $8-10$, superimposed on the $\nu_{\mathrm{s}} / \nu_{\text {as }}$ doublet.

These observations conform with a proposal according to which the $\mathrm{Mo}^{\mathrm{VI}}$ complex formed in the ternary $\mathrm{MoO}_{3}-$ $\mathrm{K}_{2} \mathrm{~S}_{2} \mathrm{O}_{7}-\mathrm{K}_{2} \mathrm{SO}_{4}$ molten system still consists of a $\mathrm{MoO}_{2}{ }^{2+}$ dioxo core and coordinated sulfate ligands. More specifically, the spectral evidence described above points to a reaction "following up" the 1:1 reaction taking place in the binary $\mathrm{MoO}_{3}-\mathrm{K}_{2} \mathrm{~S}_{2} \mathrm{O}_{7}$ molten system with the involvement of one more $\mathrm{SO}_{4}$ ligand coordinated per Mo atom in a 1:1:1 $\mathrm{MoO}_{3} /$ $\mathrm{K}_{2} \mathrm{~S}_{2} \mathrm{O}_{7} / \mathrm{K}_{2} \mathrm{SO}_{4}$ stoichiometry according to

$$
m \mathrm{MoO}_{3}+m \mathrm{~S}_{2} \mathrm{O}_{7}{ }^{2-}+m \mathrm{SO}_{4}{ }^{2-} \rightarrow\left[\mathrm{MoO}_{2}\left(\mathrm{SO}_{4}\right)_{3}\right]_{m}{ }^{4 m-}
$$

where the reaction is written in a generalized form to account for the formation of associated/polymeric molybdenum(VI) oxosulfato complexes. Figure 11 shows the Raman spectra

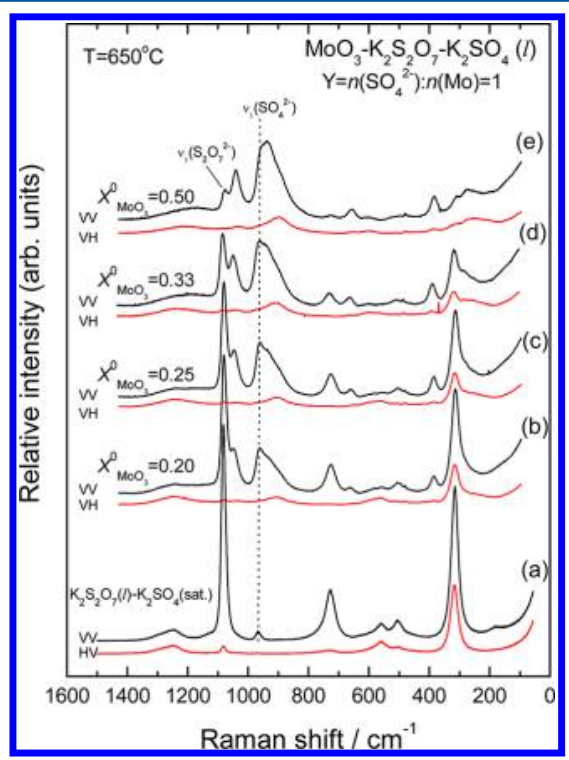

Figure 11. Raman spectra of molten $\mathrm{MoO}_{3}-\mathrm{K}_{2} \mathrm{~S}_{2} \mathrm{O}_{7}-\mathrm{K}_{2} \mathrm{SO}_{4}$ mixtures with $Y=1$ [i.e., $n\left(\mathrm{SO}_{4}{ }^{2-}\right) / n(\mathrm{Mo})=1$ ] obtained in an oxygen atmosphere $\left(P_{\mathrm{O}_{2}}=0.2 \mathrm{~atm}\right)$ at $650{ }^{\circ} \mathrm{C}$ with $\mathrm{X}_{\mathrm{MoO}_{3}}^{0}$ as indicated by each spectrum. $X_{\mathrm{MoO}_{3}}^{0}$ denotes the formal mole fraction of $\mathrm{MoO}_{3}$ in the binary $\mathrm{MoO}_{3}-\mathrm{K}_{2} \mathrm{~S}_{2} \mathrm{O}_{7}$ mixture. For spectrum recording parameters, see the caption of Figure 2.

obtained at $650{ }^{\circ} \mathrm{C}$ for the ternary $\mathrm{MoO}_{3}-\mathrm{K}_{2} \mathrm{~S}_{2} \mathrm{O}_{7}-\mathrm{K}_{2} \mathrm{SO}_{4}$ mixtures with $Y=n\left(\mathrm{SO}_{4}{ }^{2-}\right) / n(\mathrm{Mo})=1$ and formal $\mathrm{MoO}_{3}$ contents of $X_{\mathrm{MoO}_{3}}^{0}=0.20$ (Figure $11 \mathrm{~b}$ ), $X_{\mathrm{MoO}_{3}}^{0}=0.25$ (Figure 11c), $X_{\mathrm{MoO}_{3}}^{0}=0.33$ (Figure 11d), and $X_{\mathrm{MoO}_{3}}^{0}=0.50$ (Figure 11e). It is seen that, with increasing $X_{\mathrm{MoO}_{3}}^{0}$, the bands ascribed to the molybdenum(VI) oxosulfato complex, 
$\left[\mathrm{MoO}_{2}\left(\mathrm{SO}_{4}\right)_{3}\right]_{m}^{4 m-}$, increase in intensity relative to the intensities of the "solvent" bands due to $\mathrm{S}_{2} \mathrm{O}_{7}{ }^{2-}$ and $\mathrm{SO}_{4}{ }^{2-}$.

The second part of Table 2 summarizes Raman band wavenumbers, intensity and polarization characteristics, and band assignments, as discussed in the next section, along with the proposed structural models for $\left[\mathrm{MoO}_{2}\left(\mathrm{SO}_{4}\right)_{3}\right]_{m}{ }^{4 m-}$.

Structural Models for $\mathrm{MoO}_{2}\left(\mathrm{SO}_{4}\right)_{3}{ }^{4-}$ and $\left[\mathrm{MoO}_{2}\left(\mathrm{SO}_{4}\right)_{3}\right]_{m}{ }^{4 m-}$. The proposed structural models for $\mathrm{MoO}_{2}\left(\mathrm{SO}_{4}\right)_{3}{ }^{4-}$ in its monomeric and associated/polymeric form, $\left[\mathrm{MoO}_{2}\left(\mathrm{SO}_{4}\right)_{3}\right]_{m}{ }^{4 m-}$, are inspired from the crystal structures of the compounds $\mathrm{K}_{4} \mathrm{MoO}_{2}\left(\mathrm{SO}_{4}\right)_{3}$ and $\mathrm{Na}_{4} \mathrm{MoO}_{2}\left(\mathrm{SO}_{4}\right)_{3}$, respectively. ${ }^{22,23}$ As stated earlier, in the context of the discussion pertaining to Figures 8-10, the existence of a strong polarized band at $935 \mathrm{~cm}^{-1}$ and a weaker depolarized band at $895 \mathrm{~cm}^{-1}$ is in full conformity with the occurrence of a dioxo $\mathrm{MoO}_{2}{ }^{2+}$ unit (i.e., corresponding to its symmetric and antisymmetric stretching modes) within $\mathrm{MoO}_{2}\left(\mathrm{SO}_{4}\right)_{3}{ }^{4-}$ and $\left[\mathrm{MoO}_{2}\left(\mathrm{SO}_{4}\right)_{3}\right]_{m}{ }^{4 m-}$. By taking into account the established existence of a dioxo $\mathrm{MoO}_{2}{ }^{2+}$ core with coordinated sulfate ligands and invoking a 6-fold coordination for $\mathrm{Mo}$, we propose the structural model depicted in Figure $12 \mathrm{~A}$ for the monomeric $\mathrm{MoO}_{2}\left(\mathrm{SO}_{4}\right)_{3}{ }^{4-}$ anionic

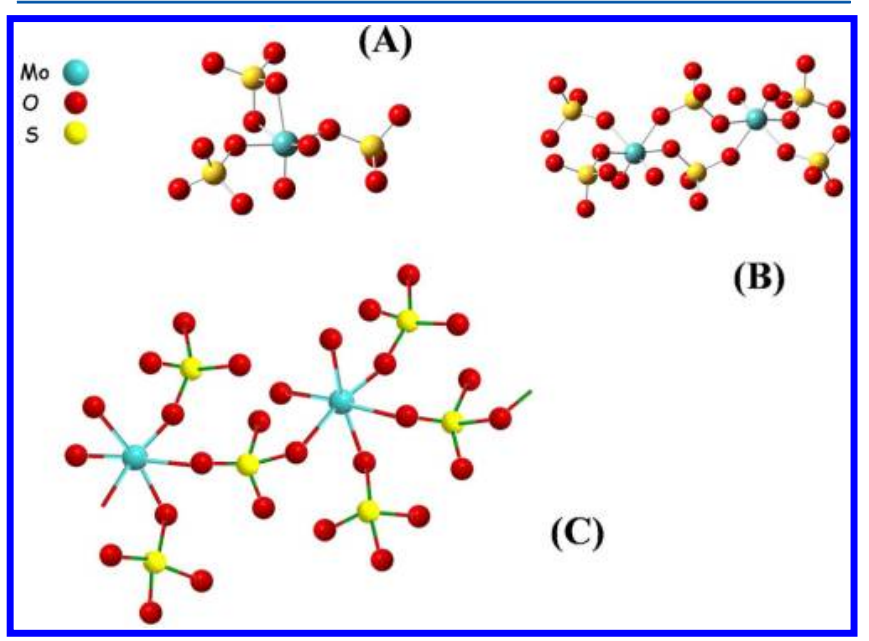

Figure 12. (A) Structural model for the monomer $\mathrm{MoO}_{2}\left(\mathrm{SO}_{4}\right)_{3}{ }^{4-}$ molten complex, according to ab initio DFT/B3LYP/3-21G calculations. (B) Structural model for the $\left[\left\{\mathrm{MovI}^{\mathrm{VI}} \mathrm{O}_{2}\left(\mathrm{SO}_{4}\right)_{2}\right\}_{2}(\mu\right.$ $\left.\left.\mathrm{SO}_{4}\right)_{2}\right]^{8-}$ dimer complex with two bridging sulfate groups and four unidentate terminal sulfate groups. (C) Plausible section of an associated/polymeric $\left[\mathrm{MoO}_{2}\left(\mathrm{SO}_{4}\right)_{3}\right]_{m}{ }^{4 m-}$ molten complex.

complex. The proposed configuration involves two unidentate sulfate groups and one bidentate chelating group. The oxide ligands occupy one apical and one equatorial position, thereby forming a bent $\mathrm{MoO}_{2}{ }^{2+}$ unit. The remaining four corners of the $\mathrm{MoO}_{6}$ distorted octahedron constituting the first coordination sphere of Mo comprise $\mathrm{O}$ atoms linking to two unidentate and one bidentate chelating $\mathrm{SO}_{4}$ groups. With increasing formal content of $\mathrm{MoO}_{3}$, the bidentate chelating sulfate group "opens up" to become bridging to an adjacent Mo atom, and the vacant coordination site can be occupied by a bridging sulfate from another adjacent $\mathrm{MoO}_{2}\left(\mathrm{SO}_{4}\right)_{3}{ }^{4-}$ unit, thereby leading to the double bridged associated/polymeric configurations shown in Figure 12B,C.

Of special interest is the following discussion on the vibrational properties of the $\left[\mathrm{MoO}_{2}\left(\mathrm{SO}_{4}\right)_{2}\right]_{m}{ }^{2 m-}$ and $\left[\mathrm{MoO}_{2}\left(\mathrm{SO}_{4}\right)_{3}\right]_{m}{ }^{4 m-}$ molybdenum(VI) oxosulfato complexes formed in the $\mathrm{MoO}_{3}-\mathrm{K}_{2} \mathrm{~S}_{2} \mathrm{O}_{7}$ and $\mathrm{MoO}_{3}-\mathrm{K}_{2} \mathrm{~S}_{2} \mathrm{O}_{7}-\mathrm{K}_{2} \mathrm{SO}_{4}$ molten mixtures, respectively. The $\nu_{\mathrm{s}} / \nu_{\mathrm{as}}$ pair of the $\mathrm{Mo}(=$ $\mathrm{O})_{2}$ symmetric and antisymmetric stretching modes occurs at $935 / 895 \mathrm{~cm}^{-1}$ for the $\mathrm{MoO}_{2}\left(\mathrm{SO}_{4}\right)_{3}{ }^{4-}$ complex, that is, ca. 25 $\mathrm{cm}^{-1}$ lower compared to the respective $957 / 918 \mathrm{~cm}^{-1}$ counterparts of the $\mathrm{MoO}_{2}\left(\mathrm{SO}_{4}\right)_{2}{ }^{2-}$ complex. The wavenumbers, band relative intensities, and polarization characteristics of both $\nu_{\mathrm{s}} / \nu_{\text {as }}$ pairs are in full conformity with the expected vibrational properties for symmetric and antisymmetric stretching modes of a transition-metal dioxo $M(=\mathrm{O})_{2}$ unit (see also Table 3 for a summary of characteristic vibrational wavenumbers). The more congested coordination around the $\mathrm{Mo}$ atom of the $\mathrm{MoO}_{2}\left(\mathrm{SO}_{4}\right)_{3}{ }^{4-}$ complex (i.e., one more sulfate per Mo compared to the $\mathrm{MoO}_{2}\left(\mathrm{SO}_{4}\right)_{2}{ }^{2-}$ species (see the proposed structural models in Figures 4 and 12) accounts for slightly weaker bonding within its $\mathrm{MoO}_{2}{ }^{2+}$ cores and lower band wavenumbers for its $\nu_{\mathrm{s}} / \nu_{\mathrm{as}}$ modes. Furthermore, the occurrence of unidentate $\mathrm{SO}_{4}$ groups among the $\mathrm{SO}_{4}$ groups within the $\mathrm{MoO}_{2}\left(\mathrm{SO}_{4}\right)_{3}{ }^{4-}$ complex formed in the ternary system justifies a lower wavenumber for the terminal $\mathrm{S}-\mathrm{O}$ stretching compared with the (exclusively) bidentate $\mathrm{SO}_{4}$ units participating in the $\mathrm{MoO}_{2}\left(\mathrm{SO}_{4}\right)_{2}{ }^{2-}$ and $\left[\mathrm{MoO}_{2}\left(\mathrm{SO}_{4}\right)_{2}\right]_{m}{ }^{2 m-}$ complexes in the binary system (1041 versus $\left.1046 \mathrm{~cm}^{-1}\right)$.

$\mathrm{Ab}$ Initio Modeling of $\mathrm{MoO}_{2}\left(\mathrm{SO}_{4}\right)_{3}{ }^{4-}$ and $\left[\left\{\mathrm{MoO}_{2}\right\}_{2}\left(\mathrm{SO}_{4}\right)_{4}\left(\boldsymbol{\mu}-\mathrm{SO}_{4}\right)_{2}\right]^{8-}$. Based on the crystal structures of $\mathrm{K}_{4}\left[\mathrm{MoO}_{2}\left(\mathrm{SO}_{4}\right)_{3}\right]^{22}$ and $\mathrm{K}_{8}\left[\left\{\mathrm{~W}^{\mathrm{VI}} \mathrm{O}_{2}\left(\mathrm{SO}_{4}\right)_{2}\right\}_{2}\left(\mu-\mathrm{SO}_{4}\right)_{2}\right]$, ${ }^{20}$ we calculated optimized geometric structures for the $\left[\mathrm{MoO}_{2}\left(\mathrm{SO}_{4}\right)_{3}\right]^{4-}$ anion and the analogous $\mathrm{Mo}^{\mathrm{VI}}$ anion $\left[\left\{\mathrm{Mo}^{\mathrm{VI}} \mathrm{O}_{2}\left(\mathrm{SO}_{4}\right)_{2}\right\}_{2}\left(\mu-\mathrm{SO}_{4}\right)_{2}\right]^{8-}$ (see Figure 12A,B). The modeling was limited to the available $3-21 \mathrm{G}$ basis set for molybdenum, but the predicted geometry for the $\left[\mathrm{MoO}_{2}\left(\mathrm{SO}_{4}\right)_{3}\right]^{4-}$ anion came out with reasonable parameters, as seen in Table S3 (Supporting Information). From that geometry, we calculated the vibrational modes for $\left[\mathrm{MoO}_{2}\left(\mathrm{SO}_{4}\right)_{3}\right]^{4-}$ (see Table S4, Supporting Information) and the spectrum (shown in Figure 13). The structure and spectrum were calculated with the Gaussian 03W program. $^{34}$ The calculated wavenumbers had to be scaled by a factor of 1.22 to obtain acceptable values compared to experiment, but this is understandable because the $3-21 \mathrm{G}$ basis set is very simple. The chosen 3-21G basis set is the largest all-electron set available for molybdenum in Gaussian. This level of theory is known to be deficient for hypervalent molecules because of a lack of polarization functions, and anions generally require diffuse functions. The use of this $3-21 \mathrm{G}$ set would result in S$\mathrm{O}$ distances that are too long and frequencies that are too small. This explains the need for scaling by a number larger than 1 . It should be remembered that the corresponding experimental mixture $X_{\mathrm{MoO}_{3}}^{0}=0.50$ and $Y=1$ (see Figure 10e) was in a state of equilibrium and, therefore, even for $\mathrm{MoO}_{3} / \mathrm{K}_{2} \mathrm{~S}_{2} \mathrm{O}_{7} / \mathrm{K}_{2} \mathrm{SO}_{4}=$ 1:1:1 (in analogy with what was seen for tungsten ${ }^{21}$ ), gave signals corresponding to the content of $\mathrm{S}_{2} \mathrm{O}_{7}{ }^{2-}$. The band shapes at the high experimental temperature were modeled by assuming Gaussian shapes of $20 \mathrm{~cm}^{-1}$ half-widths at halfheights. Two configurations were tried for the monomer, but the one similar to that of the crystal structure ${ }^{22}$ was found to be the most stable (Figure 12A). It seems that chelation taking place opposite to the two oxide ligands (from $\left[\mathrm{MoO}_{2}\right]^{2+}$ ) is preferred (minimum energy $=-6194.34847461 \mathrm{Ha}$ ) relative to a configuration where the two oxide ligands (in $\left[\mathrm{MoO}_{2}\right]^{2+}$ ) are opposite to one terminal sulfate and one of the chelations (minimum energy $=-6194.33727020 \mathrm{Ha})$. For the dimer 


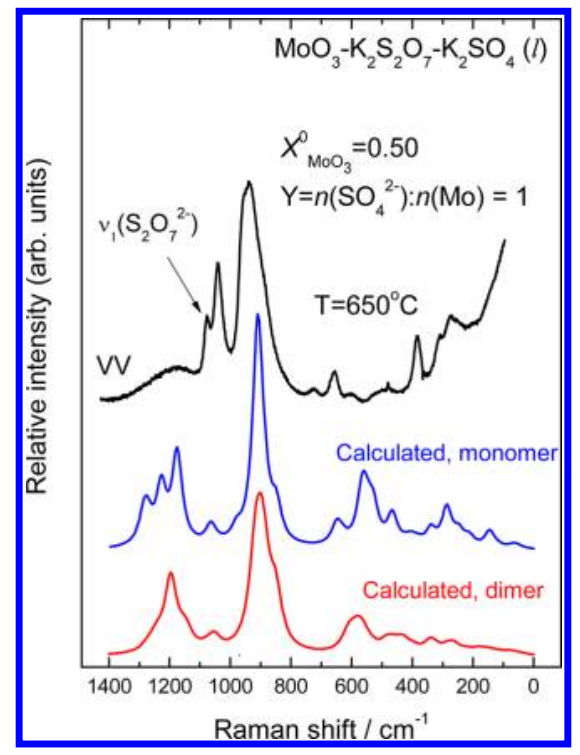

Figure 13. Comparison of the experimental Raman spectrum for the molten ternary mixture with $X_{\mathrm{MoO}_{3}}^{0}=0.50$ and $Y=1$ at $650{ }^{\circ} \mathrm{C}$ (top) and spectra of monomeric $\left[\mathrm{MoO}_{2}\left(\mathrm{SO}_{4}\right)_{3}\right]^{4-}$ and dimeric $\left[\left\{\mathrm{Mo}^{\mathrm{VI}} \mathrm{O}_{2}\left(\mathrm{SO}_{4}\right)_{2}\right\}_{2}\left(\mu-\mathrm{SO}_{4}\right)_{2}\right]^{8-}$ ions calculated by ab initio DFT/ $\mathrm{B} 3 \mathrm{LYP} / 3-21 \mathrm{G}$ modeling in the isolated state. The calculated wavenumbers have been scaled by a factor of 1.22 . Band shapes were modeled by assuming Gaussian shapes of $20 \mathrm{~cm}^{-1}$ half-widths at half-heights, corresponding approximately to the high temperature of $650{ }^{\circ} \mathrm{C}$.

$\left[\left\{\mathrm{Mo}^{\mathrm{VI}} \mathrm{O}_{2}\left(\mathrm{SO}_{4}\right)_{2}\right\}_{2}\left(\mu-\mathrm{SO}_{4}\right)_{2}\right]^{8-}$, the calculated minimum was found to be $-12387.69014870 \mathrm{Ha}(=-6193.84505745 \times 2$ $\mathrm{Ha}$ ). The structure of the optimized dimer geometry is given in Figure 12B, and the spectrum is also included in Figure 13. The 102 normal modes of the dimer appear similar to the 48 modes of the monomer (Table S4, Supporting Information). Because the sulfates in the dimer are all unidentately terminal bound, the spectrum is simpler, and the minimum energy is not as low as in the monomer.

\section{CONCLUSIONS}

Solid molybdenum(VI) oxide dissolves in considerable amounts (i.e., up to $X_{\mathrm{MoO}_{3}}^{0}=0.50$ ) in molten $\mathrm{K}_{2} \mathrm{~S}_{2} \mathrm{O}_{7}$ at elevated temperatures $\left(400{ }^{\circ} \mathrm{C}\right)$. The effects of composition and temperature on the molecular structure and vibrational properties of the molybdenum(VI) oxosulfato complexes formed were studied by Raman spectroscopy up to $640{ }^{\circ} \mathrm{C}$ and for $0 \leq X_{\mathrm{MoO}_{3}}^{0} \leq 0.50$. The spectral features are fully consistent with the occurrence of a dioxo $\mathrm{MoO}_{2}{ }^{2+}$ configuration as a core, with Mo in a distorted octahedral 6-fold coordination. The Raman band intensities were used to infer the stoichiometry of the complex formation reaction, and in combination with the vibrational properties established, it was found that the dissolution reaction has a 1:1 stoichiometry, that is

$$
m \mathrm{MoO}_{3}+m \mathrm{~S}_{2} \mathrm{O}_{7}{ }^{2-} \rightarrow\left[\mathrm{MoO}_{2}\left(\mathrm{SO}_{4}\right)_{2}\right]_{m}{ }^{2 m-}
$$

accounting for the formation of monomeric $(m=1)$ species in dilute melts and associated/polymeric units $(m>1)$ in more concentrated melts. Two bidentate chelating sulfates are present in the Mo coordination sphere in the case of momomeric $\mathrm{MoO}_{2}\left(\mathrm{SO}_{4}\right)_{2}{ }^{2-}$, whereas alternative possibilities involving bidentate bridging sulfates are incurred in the case of polymeric $\left[\mathrm{MoO}_{2}\left(\mathrm{SO}_{4}\right)_{2}\right]_{m}{ }^{2 m-}$ units. The symmetric and antisymmetric $\mathrm{O}=\mathrm{Mo}=\mathrm{O}$ stretching $\left(\nu_{\mathrm{s}}\right.$ and $\left.\nu_{\mathrm{as}}\right)$ occur at $957 \mathrm{~cm}^{-1}$ (strong, polarized) and $918 \mathrm{~cm}^{-1}$ (medium, depolarized), respectively, whereas the terminal $\mathrm{S}-\mathrm{O}$ stretching of coordinated sulfates is observed at $1046 \mathrm{~cm}^{-1}$. With increasing temperature in concentrated melts (i.e., $X_{\mathrm{MoO}_{3}}^{0} \geq$ 0.40), a partial dissociation is evidenced, leading to the formation of Mo-O-Mo bridges as "defects" within the polymeric chains.

The study of the corresponding dissolution reaction of $\mathrm{MoO}_{3}$ in $\mathrm{K}_{2} \mathrm{~S}_{2} \mathrm{O}_{7}$ when $\mathrm{K}_{2} \mathrm{SO}_{4}$ is also present showed that a modified molybdenum(VI) oxosulfato complex is formed according to

$$
m \mathrm{MoO}_{3}+m \mathrm{~S}_{2} \mathrm{O}_{7}{ }^{2-}+m \mathrm{SO}_{4}{ }^{2-} \rightarrow\left[\mathrm{MoO}_{2}\left(\mathrm{SO}_{4}\right)_{3}\right]_{m}{ }^{4 m-}
$$

The Raman spectra showed that the resulting $\mathrm{Mo}^{\mathrm{VI}}$ complex still contains a dioxo $\mathrm{MoO}_{2}{ }^{2+}$ core with the Mo atom in a modified distorted octahedral 6-fold coordination. The coordination sphere around each Mo atom involves (apart from the two oxide ligands) two unidentate sulfates and two bidentate bridging sulfates in a congested structural environment, as a result of which the $\nu_{\mathrm{s}} / \nu_{\mathrm{as}} \mathrm{Mo}(=\mathrm{O})_{2}$ stretching counterparts occur at lower wavenumbers, namely, $935 \mathrm{~cm}^{-1}$ (strong, polarized) and $895 \mathrm{~cm}^{-1}$ (medium, depolarized), respectively. Detailed structural models are proposed for the $\mathrm{Mo}^{\mathrm{VI}}$ complexes in full consistency with the Raman band assignments and $\mathrm{ab}$ initio modeling.

\section{ASSOCIATED CONTENT}

\section{S Supporting Information}

Relative integrated reduced Raman intensities (peak areas in arbitrary units) of representative bands of the $\mathrm{C}^{2 n-} \mathrm{Mo}^{\mathrm{VI}}$ complex (at $957 \mathrm{~cm}^{-1}$ ) and the $\mathrm{S}_{2} \mathrm{O}_{7}{ }^{2-}$ solvent (at 1085 $\mathrm{cm}^{-1}$ ) measured from the Raman spectra of molten $\mathrm{MoO}_{3}-$ $\mathrm{K}_{2} \mathrm{~S}_{2} \mathrm{O}_{7}$ mixtures at $450{ }^{\circ} \mathrm{C}$ (Table $\mathrm{S} 1$ ); calculated equilibrium mole fractions of $\mathrm{Mo}^{\mathrm{VI}}$ complex $\left(\mathrm{C}^{2 n-}\right)$ and $\mathrm{S}_{2} \mathrm{O}_{7}{ }^{2-}$ and values of $I^{0}$ (based on the main complex band at $957 \mathrm{~cm}^{-1}$ ) for various assumed possible values for the stoichiometric coefficient, $n$, of eq 1 (Table S2); comparison of the geometric parameters of an isolated $\left[\mathrm{MoO}_{2}\left(\mathrm{SO}_{4}\right)_{3}\right]^{4-}$ ion calculated by ab initio/DFT methods (restricted B3LYP/3-21G) and found for the X-ray structure of the $\mathrm{K}_{4}\left[\mathrm{MoO}_{2}\left(\mathrm{SO}_{4}\right)_{3}\right]^{22}$ (Table S3); and calculated vibrational spectra and assignments for the $\left[\mathrm{MoO}_{2}\left(\mathrm{SO}_{4}\right)_{3}\right]^{4-}$ ion (Table S4). This material is available free of charge via the Internet at http://pubs.acs.org.

\section{AUTHOR INFORMATION}

\section{Corresponding Author}

*E-mail: bogosian@iceht.forth.gr. Phone +30-2610 969557.

\section{Notes}

The authors declare no competing financial interest.

\section{REFERENCES}

(1) Boghosian, S.; Borup, F.; Chrissanthopoulos, A. Catal. Lett. 1997, 48,145 .

(2) Boghosian, S. J. Chem. Soc., Faraday Trans. 1998, 94, 3463.

(3) Boghosian, S.; Chrissanthopoulos, A.; Fehrmann, R. J. Phys. Chem. B 2002, 106, 49.

(4) Lapina, O. B.; Bal'zhinimaev, B.; Boghosian, S.; Eriksen, K. M.; Fehrmann, R. Catal. Today 1999, 51, 469.

(5) Boghosian, S.; Berg, R. W. Appl. Spectrosc. 1999, 53, 565.

(6) Berg, R. W.; Thorup, N. Inorg. Chem. 2005, 44, 3485. 
(7) Paulsen, A. L.; Borup, F.; Berg, R. W.; Boghosian, S. J. Phys. Chem. A 2010, 114, 7485.

(8) Paulsen, A. L.; Kalampounias, A. G.; Berg, R. W.; Boghosian, S. J. Phys. Chem. A 2011, 115, 4214.

(9) Fehrmann, R.; Krebs, B.; Papatheodorou, G. N.; Berg, R. W.; Bjerrum, N. J. Inorg. Chem. 1986, 25, 1571.

(10) Berg, R. W.; Boghosian, S.; Bjerrum, N. J.; Fehrmann, R.; Krebs, B.; Strater, N.; Mortensen, O. S.; Papatheodorou, G. N. Inorg. Chem. 1993, 32, 4714.

(11) Boghosian, S.; Fehrmann, R.; Nielsen, K. Acta Chem. Scand. 1994, 48, 724 .

(12) Fehrmann, R.; Boghosian, S.; Berg, R. W.; Papatheodorou, G. N.; Nielsen, K.; Bjerrum, N. J. Inorg. Chem. 1989, 28, 1847.

(13) Fehrmann, R.; Boghosian, S.; Berg, R. W.; Papatheodorou, G. N.; Nielsen, K.; Bjerrum, N. J. Inorg. Chem. 1990, 29, 3294.

(14) Boghosian, S.; Eriksen, K. M.; Fehrmann, R.; Nielsen, K. Acta Chem. Scand. 1995, 49, 703.

(15) Nielsen, K.; Boghosian, S.; Fehrmann, R; Berg, R. W. Acta Chem. Scand. 1999, 53, 15.

(16) Karydis, D. A.; Boghosian, S.; Nielsen, K.; Eriksen, K. M.; Fehrmann, R. Inorg. Chem. 2002, 41, 2417.

(17) Rasmussen, S. B.; Boghosian, S.; Nielsen, K.; Eriksen, K. M.; Fehrmann, R. Inorg. Chem. 2004, 43, 3697.

(18) Borup, F.; Berg, R. W.; Nielsen, K. Acta Chem. Scand. 1990, 44, 328.

(19) Ståhl, K.; Berg, R. W. Acta Crystallogr. E: Struct. Rep. Online 2009, E64, i88.

(20) Cline Schäffer, S. J.; Berg, R. W. Acta Crystallogr. E: Struct. Rep. Online 2005, E61, i49.

(21) Berg, R. W.; Ferré, I. M.; Cline Schäffer, S. J. Vib. Spectrosc. 2006, 42, 346

(22) Cline Schäffer, S. J.; Berg, R. W. Acta Crystallogr. E: Struct. Rep. Online 2008, E64, i20.

(23) Cline Schäffer, S. J.; Berg, R. W. Acta Crystallogr. E: Struct. Rep. Online 2008, E64, i73.

(24) Boghosian, S.; Fehrmann, R.; Bjerrum, N. J.; Papatheodorou, G. N. J. Catal. 1989, 119, 121.

(25) Eriksen, K. M.; Karydis, D. A.; Boghosian, S.; Fehrmann, R. J. Catal. 1995, 155, 32.

(26) Christodoulakis, A.; Boghosian, S. J. Catal. 2003, 215, 139.

(27) Tsilomelekis, G.; Boghosian, S. Catal. Today 2010, 158, 146.

(28) Tian, H.; Roberets, C. A.; Wachs, I. E. J. Phys. Chem. C 2010, $114,14110$.

(29) Tsilomelekis, G.; Boghosian, S. J. Phys. Chem. C 2011, 115, 2146.

(30) Tsilomelekis, G.; Boghosian, S. Phys. Chem. Chem. Phys. 2012, 14, 2216.

(31) Hansen, N. H.; Fehrmann, R.; Bjerrum, N. J. Inorg. Chem. 1982, 21, 744 .

(32) Boghosian, S.; Papatheodorou, G. N. J. Phys. Chem. 1989, 93, 415.

(33) Knudsen, C.; Kalampounias, A. G.; Fehrmann, R; Boghosian, S. J. Phys. Chem. B 2008, 112, 11996.

(34) Frisch, M. J.; Trucks, G. W.; Schlegel, H. B.; Scuseria, G. E.; Robb, M. A.; Cheeseman, J. R.; Montgomery, J. A., Jr.; Vreven, T.; Kudin, K. N.; Burant, J. C.; Millam, J. M.; Iyengar, S. S.; Tomasi, J.; Barone, V.; Mennucci, B.; Cossi, M.; Scalmani, G.; Rega, N.; Petersson, G. A.; Nakatsuji, H.; Hada, M.; Ehara, M.; Toyota, K.; Fukuda, R.; Hasegawa, J.; Ishida, M.; Nakajima, T.; Honda, Y.; Kitao, O.; Nakai, H.; Klene, M.; Li, X.; Knox, J. E.; Hratchian, H. P.; Cross, J. B.; Bakken, V.; Adamo, C.; Jaramillo, J.; Gomperts, R.; Stratmann, R. E.; Yazyev, O.; Austin, A. J.; Cammi, R.; Pomelli, C.; Ochterski, J. W.; Ayala, P. Y.; Morokuma, K.; Voth, G. A.; Salvador, P.; Dannenberg, J. J.; Zakrzewski, V. G.; Dapprich, S.; Daniels, A. D.; Strain, M. C.; Farkas, O.; Malick, D. K.; Rabuck, A. D.; Raghavachari, K.; Foresman, J. B.; Ortiz, J. V.; Cui, Q.; Baboul, A. G.; Clifford, S.; Cioslowski, J.; Stefanov, B. B.; Liu, G.; Liashenko, A.; Piskorz, P.; Komaromi, I.; Martin, R. L.; Fox, D. J.; Keith, T.; Al-Laham, M. A.; Peng, C. Y.; Nanayakkara, A.; Challacombe, M.; Gill, P. M. W.; Johnson, B.; Chen,
W.; Wong, M. W.; Gonzalez, C.; Pople, J. A. Gaussian 03W, revision B.04; Gaussian, Inc.: Pittsburgh, PA, 2003.

(35) Berg, R. W. Z. Naturforsch. A 2007, 62a, 157.

(36) Dyekjaer, J. D.; Berg, R. W.; Johansen, H. J. Phys. Chem. A 2003, 107, 5826.

(37) Nakamoto, K. Infrared and Raman Spectra of Inorganic and Coordination Compounds, 6th ed.; Wiley Interscience: New York, 2009.

(38) Hewett, W. D., Jr; Newton, J. H.; Weltner, W., Jr. J. Phys. Chem. $1975,24,2640$

(39) Ward, B. G.; Stafford, F. G. Inorg. Chem. 1968, 7, 2569.

(40) Beattie, I. R.; Livingstone, K. M. S.; Reynolds, D. J.; Ozin, G. A. J. Chem. Soc. A 1970, 1210.

(41) Neikrik, D. L.; Fagerli, J. C.; Smith, M. L.; Mosman, D.; Devore, T. C. J. Mol. Struct. 1991, 244, 165.

(42) Levason, W.; Narayanaswamy, R.; Ogden, J. S.; Rest, A. J.; Turff, J. W. J. Chem. Soc., Dalton Trans. 1982, 2010.

(43) Gupta., S.; Barik, A. K.; Pal, S.; Hazra, A.; Roy, S.; Butcher, R. J.; Kar, S. K. Polyhedron 2007, 26, 133.

(44) Lee, E. L.; Wachs, I. E. J. Phys. Chem. C 2007, 111, 14410.

(45) Long, D. A. Raman Spectroscopy, McGraw-Hill; London, 1977; Chapter 4.

(46) Fehrmann, R.; Gaune-Escard, M.; Bjerrum, N. J. Inorg. Chem. 1986, 25, 1132

(47) Hatem, G.; Fehrmann, R.; Gaune-Escard, M.; Bjerrum, N. J. J. Phys. Chem. 1987, 91, 195.

(48) Folkmann, G.; Hatem, G.; Fehrmann, R.; Gaune-Escard, M.; Bjerrum, N. J. Inorg. Chem. 1993, 32, 1559.

(49) Karydis, D. A.; Erisken, K. M.; Fehrmann, R.; Boghosian, S. J. Chem. Soc., Dalton Trans. 1994, 2151. 